\title{
Kernos
}

Revue internationale et pluridisciplinaire de religion grecque antique

30 | 2017

Varia

\section{Epigraphic Bulletin for Greek Religion 2014 (EBGR 2014)}

\section{Angelos Chaniotis}

\section{(2) OpenEdition \\ Journals}

Electronic version

URL: http://journals.openedition.org/kernos/2503

DOI: 10.4000/kernos.2503

ISSN: 2034-7871

\section{Publisher}

Centre international d'étude de la religion grecque antique

Printed version

Date of publication: 1 October 2017

Number of pages: 273-311

ISSN: 0776-3824

\section{Electronic reference}

Angelos Chaniotis, « Epigraphic Bulletin for Greek Religion 2014 (EBGR 2014) », Kernos [Online], 30 |

2017, Online since 01 October 2019, connection on 17 September 2020. URL : http://

journals.openedition.org/kernos/2503; DOI : https://doi.org/10.4000/kernos.2503

This text was automatically generated on 17 September 2020.

Kernos 


\title{
Epigraphic Bulletin for Greek Religion 2014 (EBGR 2014)
}

\author{
Angelos Chaniotis
}

1 The 27th issue of the EBGR presents epigraphic corpora and new epigraphic finds published in 2014. I have only included a few contributions to the reading and interpretation of old finds as well as a small selection of publications that adduce inscriptions for the study of religious phenomena. I have also summarizes some publications of 2013 and earlier years that had not been included in earlier issues of the EBGR.

2 This issue presents three corpora: the first part of the corpus of Greek and Latin inscriptions of Philippi (25), a new improved edition of the corpus of Priene (22), and the very important corpus of the inscriptions recording the visits of delegation to the sanctuary of Apollo in Klaros (52). For the most part, this issue is dedicated to newly published inscriptions. Two exciting new finds come from Apollonia; they are two lead tablets, one containing an early copy of the paian to Asklepios (28), the other containg a puzzling text. If my interpretation is correct, it is an oracle of Dodona that approves of the introduction of the cult of Asklepios in Apollonia and provides a list of offerings to various gods. Another very exciting new find comes from Thebes (103); two copies of the same epigram inscribed on a column comemmorate the discovery by a priest of a lost dedication (a shield) made by King Kroisos to Amphiaraos.

3 A new inscription from the Upper Maeander valley (116) provides information on an endowment for the cult of Asklepios and the appointment of a man as (hereditary?) priest on account of his benefactions. An interesting detail of this text is that this man had dedicated a 'statue of his piety', probably a personification of piety. A Rhodian inscription (50) attests two hitherto unknown cult associations, apparently founded by

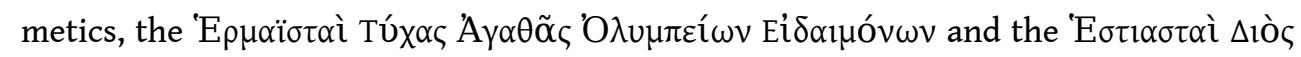

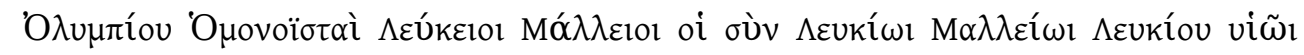

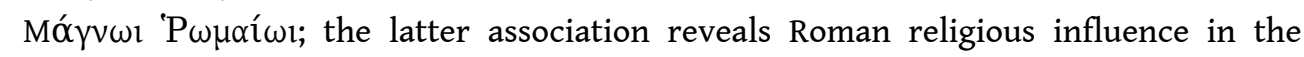
combined cult of Zeus, Homonoia, and Hestia (Vesta, Iupiter, Concordia). 
4 In addition to the above finds, I note several texts that attest the heroization of individuals (13. 48. 71. 93. 97. 119). The text from Oinoanda (93) is of particular interest, because it announces the heroization of a benefactor already before his death, i.e. his inclusion among the heroized dead of a tribe. The summarized publications cover the whole range of religious phenomena, from agonistic culture (see new evidence from Xanthos: 14) and cult regulations (e.g. 32. 106) to the imperial cult, ideas of afterlife, and magic. I single out the earliest agonistic defixio from Rome (20) and a defixio from Pantikapaion that uses the formula ó $v \omega ́ v v \mu o \zeta$.

5 The principles explained in Kernos 4 (1991), p. 287-288, and Kernos 7 (1994), p. 287, also apply to this issue. Abbreviations that are not included in the list are those of L'Année Philologique and J.H.M. STRUBBE (ed.), Supplementum Epigraphicum Graecum. Consolidated Index for Volumes XXXVI-XLV (1986-1995), Amsterdam, 1999, as well as of later volumes of the SEG. If not otherwise specified, dates are BCE. Emyr Dakin (CUNY) has improved the English text.

\section{Abbreviations}

\begin{tabular}{|c|c|}
\hline Cities and Priests & $\begin{array}{l}\text { M. HORSTER, A. KLÖCKNER (eds.), Cities and Priests. Cult Personnel in Asia Minor and the } \\
\text { Aegean Islands from the Hellenistic to the Imperial period, Berlin/Boston, } 2013 .\end{array}$ \\
\hline CGRN & $\begin{array}{l}\text { J.-M. CARBON, S. PEELS, V. PIRENNE-DELFORGE, Collection of Greek Ritual Norms, Liège } \\
\text { 2016-(http://cgrn.ulg.ac.be/). }\end{array}$ \\
\hline $\begin{array}{l}\text { Epigraphical } \\
\text { Approaches }\end{array}$ & $\begin{array}{l}\text { P. MARTZAVOU, N. PAPAZARKADAS (eds.), Epigraphical Approaches to the Post-Classical } \\
\text { Polis. Fourth Century BC to Second Century AD, Oxford, } 2013 .\end{array}$ \\
\hline $\begin{array}{l}\text { Epigraphy } \\
\text { Boeotia }\end{array}$ & $\begin{array}{l}\text { N. PAPAZARKADAS (ed.), The Epigraphy and History of Boeotia. New Finds, New Prospects, } \\
\text { Leiden, } 2014 .\end{array}$ \\
\hline $\begin{array}{l}\text { Forschungen in } \\
\text { Akarnanien }\end{array}$ & F. LANG et alii (eds.), Interdisziplinäre Forschungen in Akarnanien, Bonn, 2013. \\
\hline Mélanges Vial & $\begin{array}{l}\text { C. BALANDIER, C.CHANDEZON (eds.), Institutions, sociétés et cultes de la Méditerranée } \\
\text { antique. Mélanges d'histoire ancienne rassemblés en l'honneur de Claude Vial, } \\
\text { Bordeaux, 2014. }\end{array}$ \\
\hline Sophia adolos & 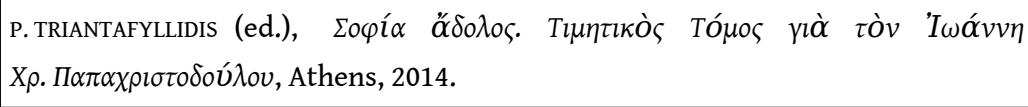 \\
\hline $\begin{array}{l}\text { Themelion } \\
\text { Themelis }\end{array}$ & 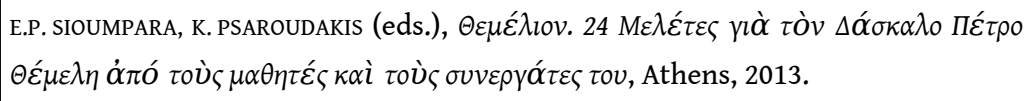 \\
\hline Threpteria & 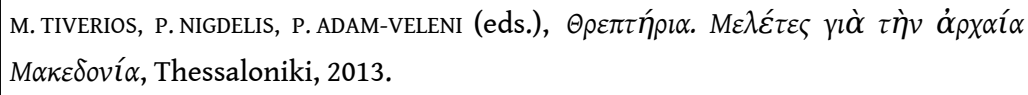 \\
\hline
\end{tabular}

\section{Selected Topics}

\section{Geographical areas (in the sequence adopted by SEG)}

6 Attica: Athens: 8. 21. 16. 26. 27. 29. 45. 58. 59. 77. 85. 90. 101. 102. 123; Eleusis: 36. Troizenia: 57. Phleiasia: Phleious: 7. Epidauria: Epidauros: 92. 113. Lakonia: 51. 83. 
138; Gytheion: 74. Messenia: 78; Messene: 95; Thouria: 4. Boiotia: Aulis: 120. Chaironeia: 61; Koroneia: 133 Lebadeia: 111; Plataiai: 73. 76; Thebes: 5. 103; Thespiai: 61. Delphi: 89. Phokis: Kalapodi: 112. Akarnania: 55. 82; Palairos: 128. Thessaly: Larisa: 56. Epirus: Dodona: 23. 28. 84. Illyria: Apollonia: 28. Macedonia: 131; Dikaia: 96; Dion: 107 Stageira: 124; Thessalonike: 1. 97. Thrace: 38. 40. 52. 129; Byzantion: 3. Moesia: 39; Novae: 81; Tomis: 12. 15. Dacia: Potaissa: 110. North Shore of the Black Sea: Pantikapaion: 17. Delos: 16. 65. 114. 136. Rhodes: 34. 50; Lindos: 106. 130. Lesbos: 21. 43. 109. Kos: 34. 91. 95. 104. 105. Chios: 16. 52. 118. Samos: 87. Thasos: 54. 60. Crete: 52. Sicily: 72; Halaisa: 46; Morgantina: 88; Syracuse: 121. Italy: Rome: 20. Asia Minor: 52. Karia: Aphrodisias: 33. 69. 95. 125; Bargasa: 86; Halikarnassos: 68; Herakleia Salbake: 52; Iasos: 19; Lagina: 137; Mylasa: 132; Panamara: 137; Stratonikeia: 137. Ionia: Ephesos: 49; Klaros: 30. 52; Miletos: 48; Phokaia: 52; Priene: 22. 95; Thebes on Mykale: 22. Lydia: Apollonia on the Maeander: 31; Philadelpheia: 127; Sardeis: 16. 75. Mysia: Attea: 71; Hadrianouthera: 127; Kyzikos: 32; Pergamon: 16. Bithynia: 2; Nikaia: 44. 98. Paphlagonia: Neuklaodiopolis: 126. Galatia: Iouliopolis: 10. Phrygia: 2. 11; Atyochorion: 116; Dorylaion: 11; Hierapolis: 41. 117; Laodikeia: 70. 52. 88. 122. Pamphylia: 6. Lykia: 115; Arykanda: 67; Oinoanda: 93; Rhodiapolis: 67; Termessos: 134; Tlos: 94; Xanthos: 13. 14. Kilikia: Seleukeia on the Kalykadnos: 24. Cyprus: 90; Amathous: 9; Kourion: 17. Syria: 119; Antioch: 79; Zeugma: 47. Palestine/Judaea: 53. Arabia: Gerasa: 64. Egypt: Thebes: 35. 80; Terenouthis: 100; Trimithis: 37.

abaton: 52

account, building: 111.113

afterlife: 25. 69. 97.101. 117

agonistic festival: 14. 78; Antipatreia : 14 (Xanthos); Asklepieia (Megala): 25 (Philippi); Dia Kleoxenia: 52 (Laodikeia); Dionysia: 85. 123 (Athens); Dionysia (Megala): 63 (Athens); Germanikeia: 21 (Athens); Letoa Traianeia Hadrianeia Antoneia: 14 (Xanthos); Panionia: 22; Soteria : 89 (Delphi); of the Lykian Koinon: 67

altar: 2. 9. 11. 19. 22. 24. 43. 64. 71; shared a.: 22. 53

2 amulet: 40.62

chorus: 52

Christianity: 37.62

cleromancy: 28

24 cult, introduction of: 29; see also s.v. funerary cult, hero cult, heroization, imperial cult, ruler cult 

9. 47. 55. 60. 90. 104. 125; Pandemos 104; Pontia 104. Apollo: 26. 30. 37. 46. 55. 61. 65. 92 104. 112. 114. 134; Amyklaios 138; Dalios 104; Delphidios 138; Karneios 104; Phoibos 81; Apotropaios 34; Hyperteleatas 51; Ismenios 5. 103; Klarios 52; Oulios 104; Platanistios 57; Pythios 26. 27. 52. 104. Artemis: 12. 60. 98. 128; Ariste 59. 77; Eileithyia 61; Gazoria 25; Kalliste 59. 77; Kolainis 45; Kombike 67; Kynegetis 115; Ladbane 67; Limnatis 78; Lochia 70. 88. 104; Toxitis 104. Asklepios: 4. 16. 26. 28. 61. 92. 104. 113. 116. Athena: 22. 24. 28. 53. 67. 104. 138; Alea 83. 138; Lindia 130; Polias 22. 67; Soteira 124. Brimo: 131. Charites: 37. 47. 104. Demeter: 104. 117. Dione: 28. Dionysos: 22. 47. 61. 76. 109. 136; Kallikarpos 8; Skyllitas 104; Thyllophoros 104. Dioskoroi: 67. Dodekatheon: 104; cf. 115. Eileithyia: 61. Eleuthera: 67. Ennodia: 34. 54; Mykaika 56; Stropika 56. Eros: 47. Ge: 55. Hekate: 34. 58. 137; Ennodia 34; Euekoos 34; Meliteina 34; Phosphoros 34; Pontia 34; Propylaia 34; Soteira 34; Stratia 34. Helene: 67. Helios: 55. Hera: 15. 22. 87. 104. 109. Herakles: 5. 37. 53. 86. 100. 104; Charops 61; Diomedonteios 104; Kallinikos 104; Prophylax 19. Hermes: 22. 24. 37. 50.53. 100. 115; Enagonios 104; Propylaios 34. Hestia: 50; Phamia 104; Prytaneia 32. Homonoia: 50. 104. Hosion Dikaion: 97. Hygieia: 4. 104. Kore: 41. 53. Leto: 14. Maia: 37. Mes: Matrios 10. Meter Theon: 61. Muses: 37. Nemesis: 104. Nike: 104. Nymphs: 104; Leibesthriades 133. Pasiphae: 138. Plouton: 41. Poseidon: 55. 67. 104. Helikonios: 22. Thea Rhome: 67. 118. 127. Themis: 28. Theos Agathos: 44. Theos Hypsistos: 53. Trophonios: 61. Tyche Agathe: 50. Zenoposeidon: 132. Zeus: 6. 15. 16. 24. 34. 40. 46. 55. 82. 109. 124. 137; Akraios 68; Alseios 104; Basileus 61. 109. 111; Boulaios 22; Bronton 2. 11. 44; Eucharistos 2; Heraios 109; Homonoios 109; Hypsistos 38; Karpodotes 2; Machaneus 104; Naios 28; Olympios 50. 53. 108; Osogollis 132; Ouebreanos 44; Phratrios 27; Polieus 104; Soter 44. 98. 104. 121. 124; Tyrrhanios 28 ? 

86

deities, Egyptian: 22. 61. 134; Isis 61; Isis Basilissa 12; Isis Regina 25; Memnon 35; Neotera 135; Sarapis 2.16. 25. 40. 61

deities, Oriental: Adonis 90

deities, Roman: Aequitas Augusti 25; Concordia 50; Cupido 25; Genius coloniae 25; Iuppiter 50; Iuppiter Optimus Maximus 25; Mercurius Augustus 25; Quies Augusta Coloniae 25; Vesta 50; Victoria Germanica 25

deities, Syrian: Thea Syria 16

deities, Thracian: Thracian Rider 25.39.129

deity: epithet, significance of: 2; god as eponymous magistrate: 52 ; libation, offered by d.: 40; patron of lightning: 56 ; protector of tombs: 56 ; punishment, divine: 94 ; river god:

deme, cult of: 27.104

Dionysiac technitai: 89

Dionysiac-Orphic tablet: 131

disease: 30

divination: 28. 30. 52.79. 84. 103; see also s.v. oracle

dream: 71. 86. 98

eagle: 38

Egyptian influence: 106

elite: 29.36 .54

endowment: 116; for priesthood: 117

ephebe: 52

family, of cult officials: 36

fate: 101.127

festival: 1. 137; foundation of: 14; funding of: 14; see also s.v. agonistic festival

first-fruit offering: 36

founder (ktistes): 86.120

funerary cult: 48.117

funerary imprecation: 75.94

gem: 3

gladiatorial combat: 1

grave, protection of: 33

gymnasion: 31

hero cult: 5 (Melission). 13 (Kybernis). 22. 25 (Heros Aulonites). 28. 39. 60 (Pontomedon). 120 (Tlepolemos). 129 (Thracian Rider)

heroization: 13. 48. 71. 93.97.117.119

historiola: 72

hymn: 28. 52

hymnody: 52 
imperial cult: 14.21 .22 .25 .29 .33 .36 .43 .48 .60 .74 .117 .125 .126 ; association of emperor with deity: 25 (Sabina/Juno)

incense burner: 25

influence on Greek religion: Egyptian: 106; Oriental: 16

invocation: 24.40

Jews: 16

ktistes: 86.120

lamp, mummiform: 79

libation: 30. 32. 133; offered by god: 40

magic: 3. 17. 79; magical names: 3. 79; magical words: 3. 79; sequence of vowels: 3. 79; see also s.v. amulet, curse

manumission: 61

mystery, of love: 47

mythology: 86. 118. 120; in Late Antiquity: 37

Neoplatonism: 69

niche: 24

oath: 55

oracle: 23. 28. 30. 52.112. 115; see also s.v. cleromancy, divination

Orphics: 131

paganism, late: 37.53 .69 .77

Panionion: 22

personification: Eusebeia: 116; Telete: 47

piety: 16

pilgrimage: 35

politics and religion: 23.120

pollution, caused by viewing: 106

priest, association of priests: 46 ; benefactions by: 116.137 ; benefactor appointed as p.: 116; consecration of: 105; dedication by: 27. 103. 128; eponymous: 67 ; family relations among: 25; honorific statue of: 95.107 ; purity of: 105 ; see also cult officials priesthood: 8; appointment: 105. 116; dispute about: 22; duties: 8. 91. 105; endowment for: 117; hereditary: 116; prestige: 29; sale of: 22. 24. 91. 104. 105

proskynema: 80

punishment, divine: 94

purification: 22.32

purity: 105

ritual: see s.v. banquet, curse, divination, invocation, libation, oath, sacrifice, supplication, theoria, vow

Roman influence: 50

ruler cult: 9 (Arsinoe II). 66. 121 (Hieron II) 
sacrifice: 30 . 31. 55. 104; commemorative: 31 ; sacrificial animals: 28 ; stone for the binding of sacrificial animals: 9

sanctuary, bank: 6. 45; of clan: 60; finances: 99; on frontier: 55; property: 116. 132. 136; recipient of fine: 33; sacred money: 45; see also s.v. account, boundary marker, thesauros

statue: 24.114 ; cult s.: 113 ; dedication of s. as festival: 52 ; of god: 30.116 ; of piety: 116 ?; of priest: $95.107 .116 ?$

suicide: 117

supplication: 96

temple: 19; decoration of: 24

theoria: 52.65

thesauros: 4

vow: 10.11. 40. 44. 87.110. 117

war, impact on religion: 63

women, and religion: 117

\section{Greek Words (a selection)}

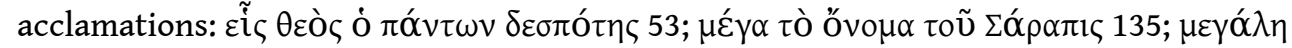

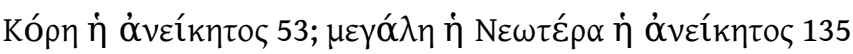

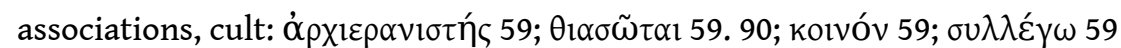

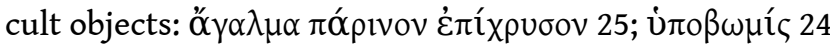

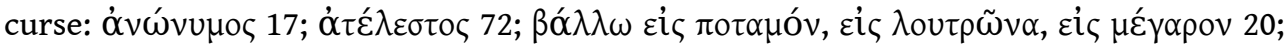

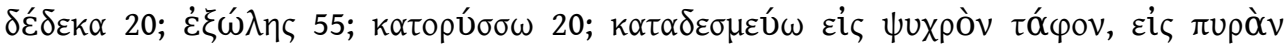

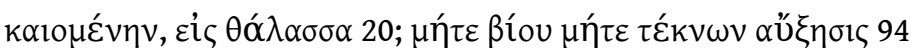

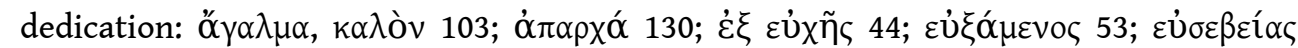

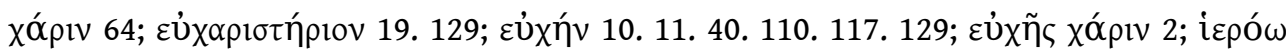

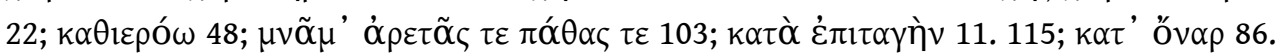

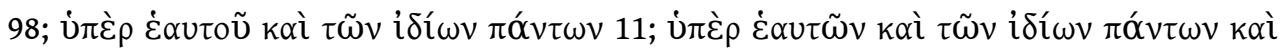

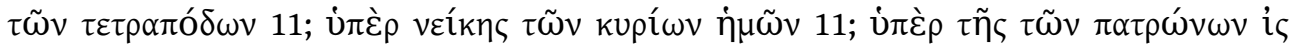

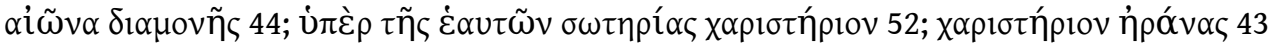

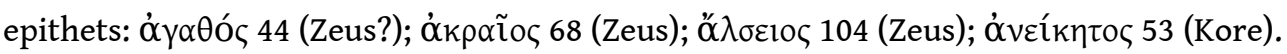

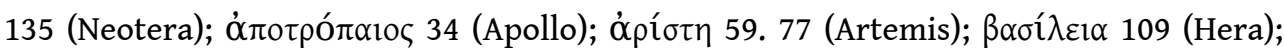

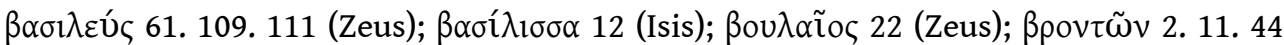

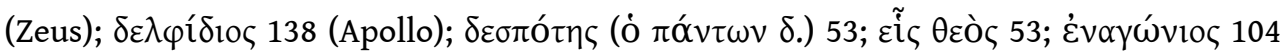

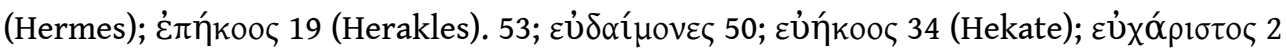

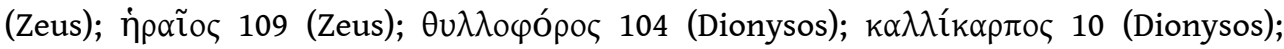

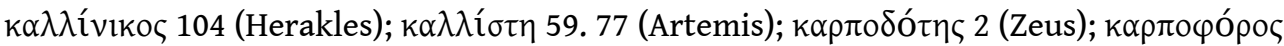

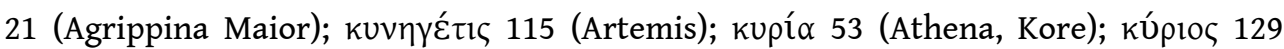

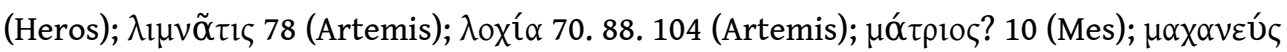

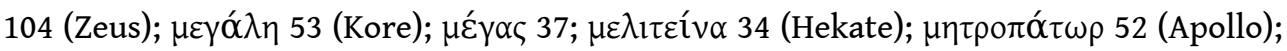

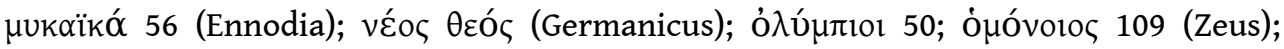

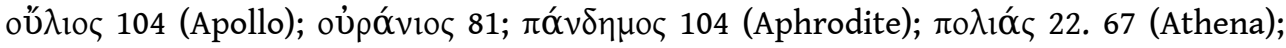




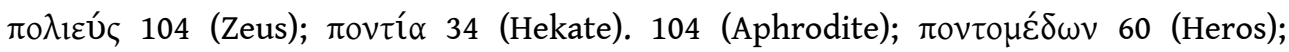

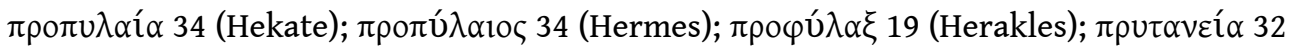

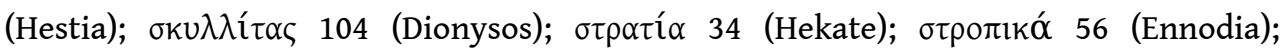

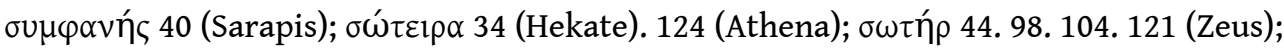

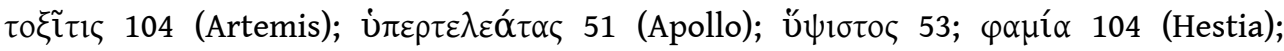

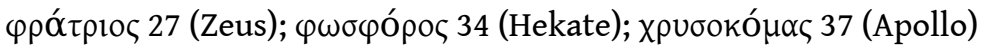
Bronton, from the modern province of Bilecik (northwest Phrygia and Bithynia). She suggests that they were originally placed on inscribed altars and were influenced by the iconography of Sarapis (2nd/3rd cent.). In this context, she publishes two

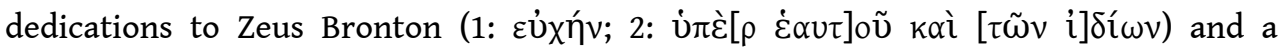

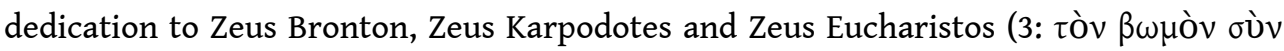

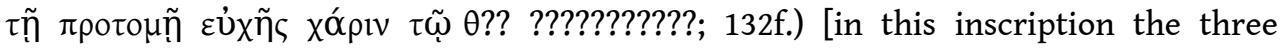
epithets of Zeus were regarded as referring to one god (??????), characterizing his different properties; for cases in which different epithets seem to refer to different hypostases of a god (e.g. Zeus Anabatenos is different from Zeus Kersoullos) see $\varepsilon \tilde{\varphi}$ $\dot{\alpha} v \varepsilon \sigma \tau \eta \dot{\sigma} \sigma \alpha \mu v$; 132f.) [in this inscription the three epithets of Zeus were regarded as referring to one god ( $\tau \tilde{\omega} \theta$ ???), characterizing his different properties; for cases in which different epithets seem to refer to different hypostases of a god (e.g. Zeus Anabatenos is different from Zeus Kersoullos) see $\varepsilon \tilde{\omega})$, characterizing his different properties; for cases in which different epithets seem to refer to different hypostases of a god (e.g. Zeus Anabatenos is different from Zeus Kersoullos) see EBGR 2012, 82]. On $167 \mathrm{n}^{\circ} 34$, she republishes a dedication to Zeus Bronton (SEG XLIII 898).

3) S. AltinoluK, N. AtaKan, "Abrasax. A Magical Gem in the Istanbul Archaeological Museum", Anatolia Antiqua 33 (2014), p. 219-223: Ed. pr. of a jasper gem from the area of Byzantion/Constantinople (district of Eminönü, Imperial period). On the obverse it 


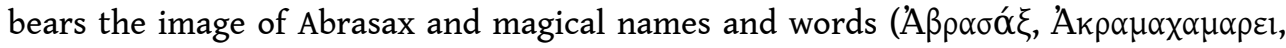
'I $\alpha$ ov, $\Sigma o \theta_{l}$ etc.) and a sequence of vowels, on the reverse magical words.

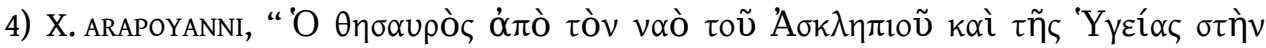

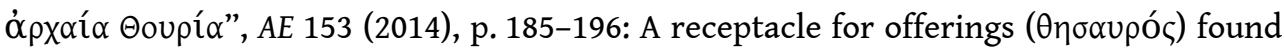
at the temple of Asklepios and Hygieia in Thouria names the two hierothytai during whose term in office it was made (late 4th/early 3rd cent.) [see already EBGR 2012, 6]. A. adduces numerous parallels for similar 'offering boxes' in sanctuaries.

5) V.L. ARAVANTINOS, "The Inscriptions from the Sanctuary of Herakles at Thebes: An Overview", in The Epigraphy of Boeotia, p. 149-210 [BE 2015, 302-303]: Recent excavations in Thebes have identified the sanctuary of Herakles on the Kadmeia. The numerous epigraphic finds include 70 vases with painted and incised inscriptions that usually designate them as dedications to Herakles (p. 158-196, 7th-6th cent.), using variants of

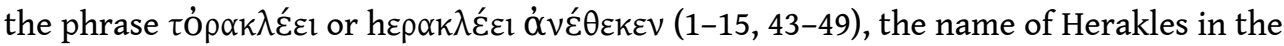
genitive (16-22), and the formula hıopó (23-33). The finds also include bronze objects: a miniature chariot dedicated by the Argives to the hitherto unattested hero Melission (5th cent.; p. 196-199); a tablet with a fragmentary document (ca. 500-450; p. 199-202) [in a preliminary publication, Aravantinos had interpreted the text as a dedication to the sons of Herakles (see EBGR 2010, 8); but the text seems to be a grant of privileges); a bronze kantharos dedicated to Apollo Ismenios (6th/5th cent.; p. 202) [mentioned in EBGR 2010, 8]. The latter object may have been brought to the sanctuary of Herakles from another shrine. On p. 206f., A. presents another dedication to Apollo Ismenios from Thebes, inscribed on a marble column (6th cent.).

6) I.N. ARnAOUtoGlou, "Displaying a Proof of Ownership in Roman Pamphylia", ZPE 191 (2014), p. 185-188 [BE 2015, 670]: A. studies a puzzling text of unknown provenance (probably from Pamphylia, 2nd/3rd cent.; BE 2014, 487; SEG LIX 1551). The text, written on a bronze tabula ansata, reports that a certain Toues purchased an orchard, confirms that the seller has received the price, and then states that 'the buyer donated the field

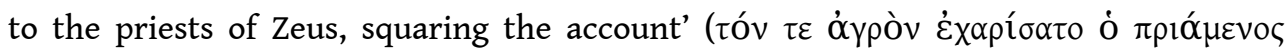

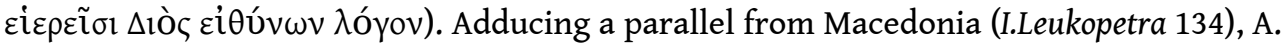
argues that Toues did not make a donation to the sanctuary of Zeus, but delivered the field that he had bought, in order to repay loans that he had received from the sanctuary (datio in solutum). The tablet was not a deed of sale but proof of ownership.

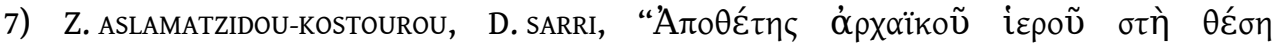

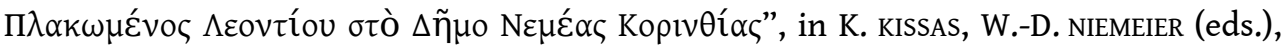
The Corinthia and the Northeast Peloponnese: Topography and History from Prehistoric Times until the End of Antiquity: Proceedings of the International Conference held at Loutraki, March 26-29, 2009, Munich, 2013, p. 397-404 [SEG LXIII 236]: The authors mention a graffito on a vase dedicated to Aphrodite (Phleious, 6th/5th cent.; p. 400f.).

134 8) M. AUGIER, "Prêtresse et ó $\rho x \eta ́$ en Attique : une aporie ? Un règlement de l'époque impériale", Ktema 38 (2013), p. 293-304 [SEG LXIII 113]: A. discusses the cult regulation of a cult association of women from Athens (1st cent. CE; IG II $^{2}$ 1346; LSCG Suppl. no. 127), focusing on the office of the priestess. She argues that the priestess had to

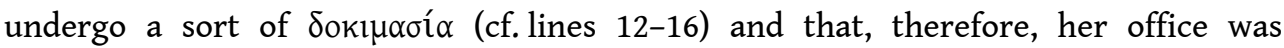
regarded as an $\dot{\alpha} \rho X \eta \dot{n}$. Other epigraphic evidence $\left(I G I^{3} 6,35\right)$ suggests that priestesses were subject to accountability. 
9) P. AUPERT, P. Flourentzos, "Inscriptions d'Amathonte X. Inscriptions grecques et latines de l'agora d'Amathonte", BCH 136/137 (2012/13), p. 363-405 [BE 2105, 34]: Ed. pr. of numerous inscriptions from the agora of Amathous, some of them of religious interest: 1) An altar for the cult of Arsinoe II Philadelphos (366-368 $n^{\circ} 1=$ SEG XLIII 1002; ca. 250). 2) A block with a hole on the right, possibly for binding sacrificial animals, was used as a boundary marker of the sacred and inviolable area of the

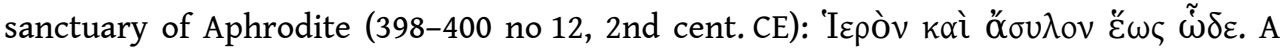
drawing under the inscription may indicate the zone that was declared as inviolable.

10) F. AVCU, Y. DoĞAN, "Epigraphic Research around Juliopolis II: New Inscriptions from Nallhhan", Gephyra 11 (2014), p. 85-99: Ed. pr. and republication of inscriptions from Iouliopolis in Galatia: 1) Ed. pr. of a dedication to Mes Matrios (عن̉xńv; 2nd/3rd cent.);

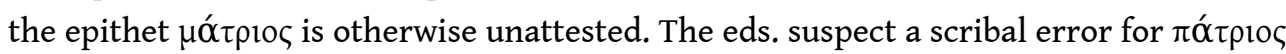
which is attested as an epithet of Mes (e.g. SEG XXX 1504) [this is a plausible

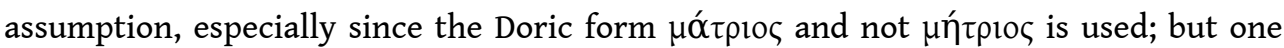
should also consider the association of Mes with a divine mother: SEG LIII 1344

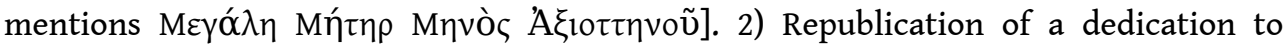
Dionysos Kallikarpos (RECAM II 155, 1st cent. CE).

11) A. AVRam, "Notes épigraphiques (III)", Pontica 46 (2013), p. 295-309: A. presents improved editions of inscriptions in the Museum of Eskişehir: 1) He corrects the name of the dedicant in a dedication to Zeus Bronton (SEG XLIV 1069, Dorylaion). 2) In a dedication to Zeus Bronton from Dorylaion (A. KÖRTE, "Kleinasiatische Studien" MDAI(A) 25 [1900], p. $\left.418 \mathrm{n}^{\circ} 30\right)$ he restores k??? ??????[?? ???? ?????? ???] | ??? ????? ?[?????

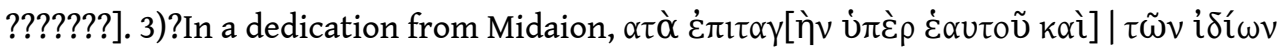

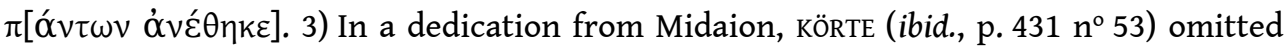
the last word: $\varepsilon$ ??[?]?. 4)?A. improves the reading of an altar from Karalar (ن̉x['́]v. 4) A.

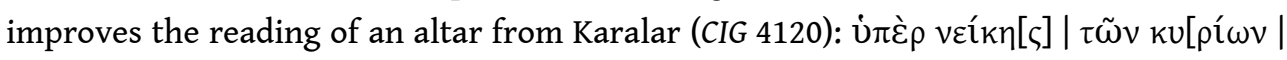

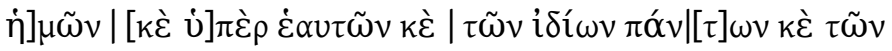
$\tau \varepsilon \tau \rho \alpha \mid[\pi]$ ó $\delta \omega v \kappa \tau \lambda$.

138 12) A. AVRAM, "Notes épigraphiques (V)", Pontica 47 (2014), p. 451-463: Ed. pr. of a dedication to Isis Basilissa and probably Artemis (Tomis, 2nd cent.): $[\tau] \tilde{\eta} \iota \beta \alpha \sigma \iota \lambda[\hat{i} \mid \sigma] \sigma \eta\langle 1$

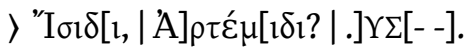

139 13) P. BAKER, G. THÉRIAULT, "Dédicace de mercenaires lagides pour Kybernis sur l'Acropole lycienne de Xanthos", in P. BRUN et alii (eds.), Euploia. La Lycie et la Carie antiques. Dynamiques des territoires, échanges et identités, Bordeaux, 2013, p. 293-302 [BE 2014, 451; SEG LXIII 1382]: Ed. pr. of an interesting dedication made by mercenary soldiers serving under the command of a certain Agathokles, probably in a Ptolemaic

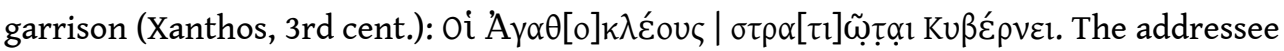
can be identified with a heroized prominent Lykian commander during the battle of

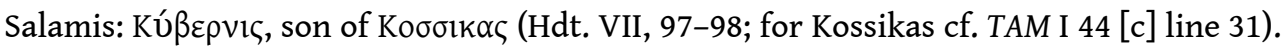
The scenes on the Pillar of the Harpyes at Xanthos (F.Xanthos I; ca. 480-470) may refer to the cultic worship of the heroized Kybernis.

14) P. BAKER, G. THÉRIAULT, "La vie agonistique xanthienne : nouvel apport épigraphique (première partie)", REG 127 (2014), p. 97-118: Ed. pr. of three inscriptions that provide information on agonistic festivals in Xanthos. A text dated to $152 / 3$ attests a contest that took place during the panegyris of the Letoa Traianeia Hadrianeia Antoneia in the

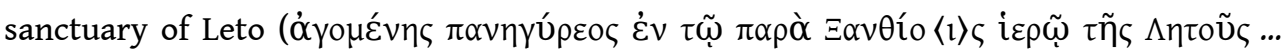




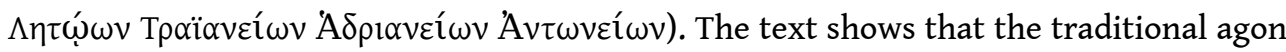
of the Letoa was successively associated with the cult of the emperors Trajan, Hadrian, and Antoninus Pius. The Letoa Traianeia were already attested through F.Xanthos VII $\mathrm{n}^{\circ}$ 69, where B.-T. restore $\Lambda$ ???[??]?? ?????????? (early 2nd?cent.). The same agon is

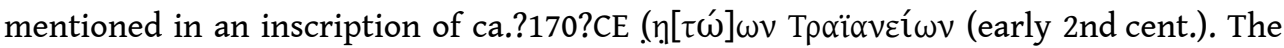
same agon is mentioned in an inscription of ca. 170 CE (F.Xanthos VII $n^{\circ} 91: \pi ? ? ? ? ? ? ?$ ??? ?? ??????? ??????); the identity of the emperor with whom the Letoa were connected is not known (Marcus Aurelius or Antoninus Pius). Two inscriptions concern the

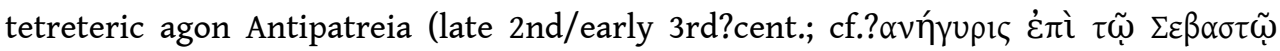
$\Lambda \eta \tau \omega \omega v)$; the identity of the emperor with whom the Letoa were connected is not known (Marcus Aurelius or Antoninus Pius). Two inscriptions concern the tetreteric agon Antipatreia (late 2nd/early 3rd cent.; cf. TAM II.1.307). The first text honors M. Aurelius Antipatros, the founder of the contest, and reports that his eternal

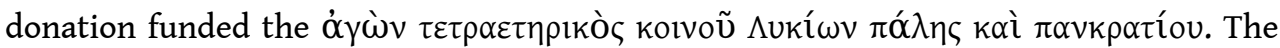
second text honors a victor in pankration in the age-class of men; the agonothetes was a descendant of the founder (M. Aur. Antipatrianos Demesthenes).

15) M. BăRbulescu, L. Buzoianu, C. BăJenaru, "Inscripţii inedite din Tomis şi din împrejurimi aflate în colecţia Muzeului de Istorie NaŢională şi Arheologie Constanţa", Pontica 47 (2014), p. 417-437: Ed. pr. of a very fragmentary dedication to Zeus (?) and Hera for the well-being of Antoninus Pius and the governor of Moesia Inferior (Tomis, $138 \mathrm{CE}$ ?). The dedication may have been made by a cult association.

16) M.-F. BASLEZ, "Les thérapeutes de Délos et d'ailleurs: l'apport de l'épigraphie délienne à l'histoire des communautés religieuses à l'époque hellénistique et romaine", in Mélanges Vial, p.109-131: The term $\theta \varepsilon p \alpha \pi \varepsilon v \tau \alpha i ́$, probably reflecting an Oriental concept about the relation between worshipper and divinity, appears for the first time in Delos in connection with the cult of Sarapis (late 3rd cent.; IG XI.4.1217; cf. papyrological attestations in Memphis: UPZ I 8), and later with that of the Thea Syria (ca. 110; I.Délos 2222, 2227-2234, 2237, 2240-2241, 2271, 2274, 2628). This designation is also attested in the late Hellenistic period in sanctuaries of the Egyptian gods in Greece and Asia Minor (RICIS 112/0703, 114/0201 and 0203, 303/0302, 301/0401 and 0402). In the Imperial period it is used in connection with a Jewish group in Alexandria and the cults of Asklepios [AvPergamon VIII.3.26, 47, 71, 79, 122, 152, 161; see now SEG LVI 1387] and Sarapis in Pergamon (I.Pergamon II 338), Zeus in Sardeis (Sardis VII.1.22), Asklepios in Athens (SEG XXI 770; see also SEG XXXIX 229) [the correct reference is SEG XXI 776, not 770], and an unknown divinity in Chios (W.G. FORREST, "Some Inscriptions of Chios", ABSA 61 [1966], p. 199f.). After detailed study of the evidence, B. concludes that the $\theta \varepsilon \rho \alpha \pi \varepsilon u \tau \alpha$ í were people who were more actively engaged in the service of gods than other worshippers. Although they did no hold priestly offices, their services, which were of very diverse nature (assistance in sacrifices and other rites, upkeep of sacred buildings, decoration of divine images etc.), approached that of the priest officiating in the cult. The $\theta \varepsilon \rho \alpha \pi \varepsilon v \tau \alpha i$ were not involved in mystic or ascetic practices; their numbers and organization varied.

17) A. Belousov, N. feDoseev, "A New Magical Inscription from Panticapaeum's Necropolis", ZPE 190 (2014), p. 145-148 [BE 2015, 78; SEG LXIII 616]: Ed. pr. of a lead tablet from the necropolis of Pantikapaion (3rd cent.); it was originally folded and pierced with a nail. The tablet is inscribed with a curse that consists of the repetition of the word $\dot{\alpha} v \omega ́ v v \mu o \varsigma$, written 18 times in two columns; a few additional letters and 


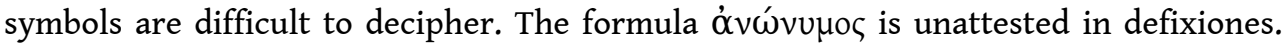
The editors assume that it is a designation of a divinity. In addition to the Erinyes and Eumenides who are sometimes called 'nameless', judicial curses from Kourion sometimes designate the untimely dead as 'nameless' (I.Kourion 127, 129, 131, 134-140,

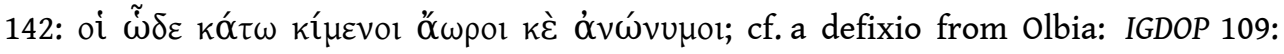

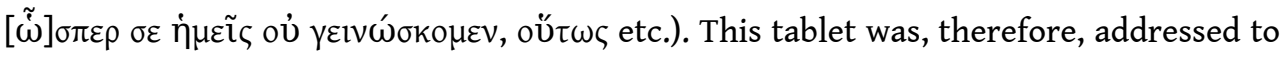
the spirit of an untimely deceased person, in whose grave it was placed.

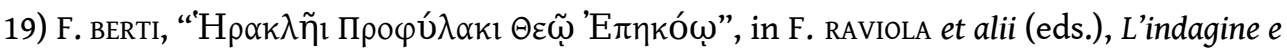
la rima. Scritti per Lorenzo Braccesi, Rome, 2013, p. 209-220 [BE 2014, 442; SEG LXIII 880]:

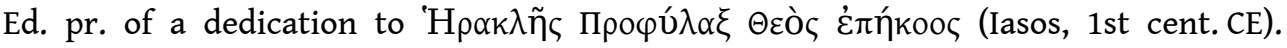
T. Cornelius Pollion covered with plaster and decorated his temple and constructed an

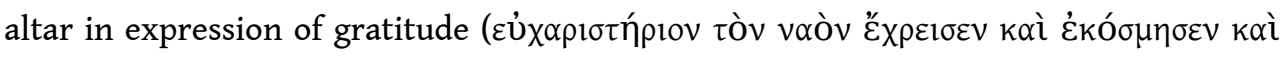

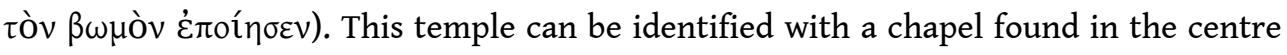
of the west stoa. The epithet Прочv́ $\lambda \alpha \xi$ was already attested at Iasos (I.Iasos 108-109).

20) G. Bevilacqua, "Athletai e palaistai in una defixio greca di Roma”, ZPE 188 (2014), p. 215-229: Ed. pr. of a defixio from Rome (1st/2nd cent.; cf. EBGR 2013, 20). The text is addressed against 17 athletes, 10 from Alexandria, the rest from Aizanoi, Ephesos, Kos,

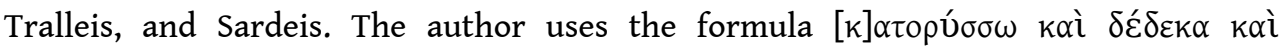

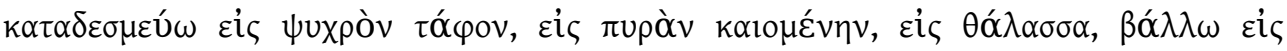

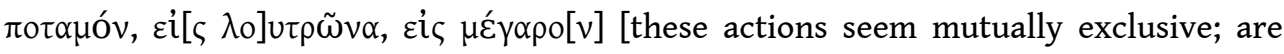
they to be understood as cumulative actions, to be performed against the victims in succession? Or were they different options mentioned in a formulary, meant to be offered for selection?]. Remains of words following the list of names show that the feet and knees of the athletes were cursed. This is the earliest Greek defixio from Rome and the only agonistic defixio from Rome that is not addressed against horses or charioteers.

21) C. BLONCE, A. GanglofF, "Mémoire du voyage de Germanicus en Orient", CCG 24 (2013), p.113-134: The authors discuss the epigraphic evidence pertaining to the journey of Germanicus and Agrippina Maior to the East (17/18 CE) and their stay in Athens and on Lesbos. Germanicus had already been honored in Athens prior to his visit (IG $\mathrm{II}^{2} 3253-$

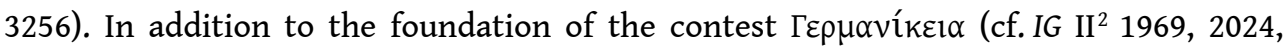
2119/2120), he received additional honors (IG II ${ }^{2} 3258 / 3259$ = SEG XXXIV 178; IG II 3260 = SEG XXXIV 179). We note that a statue-base of the 5th cent. was re-used for an honorary statue of Germanicus (IG I ${ }^{3} 511=$ Syll. $\left.^{3} 51\right)$. In Lesbos, honorific inscriptions for

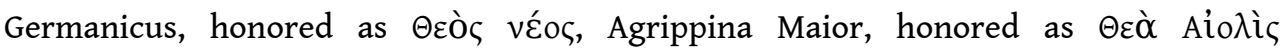
Кхрточо́роц, and their children date both to the period of their stay on Lesbos and later (IG XII.2.208, 212/213, 258, 540; IG XII Suppl. 690). Lesbos was eager to highlight its relations with Augustus, Agrippa, and Germanicus.

22) W. BLÜMel, R. MERKelBACH, Die Inschriften von Priene. Teil I. Text, zusammengestellt, übersetzt und kommentiert (IGSK 69.1), Bonn, 2014 [BE 2015, 617]: This revised edition of the corpus of Priene contains improved editions of the texts that were included in I.Priene, with numerous new readings and restorations, but also with German translations and detailed commentaries. The editors have followed a different arrangement of the texts, resulting in a new numbering. The texts that were not already included in I.Priene are not numerous. We single out a list of members of a Dionysiac association, who promised donations for the purchase of food, a field and the payment of servants (184 = SEG XXXI 983, 2nd/1st cent.). But the eds. have made substantial changes in many texts, e.g. in the edict of the governor of Asia for the 
introduction of a new calendar in honor of Augustus in $9 \mathrm{BCE}$ and the related decrees of the Hellenes of Asia $(14=$ I.Priene 105). Among the few inedita we note a few texts of religious interest: a dedication to Athena (151, 4th cent.), three altars of Athena Polias (157), boundary markers of the sanctuary of Athena Polias $(158,163$, Hellenistic and Imperial period; cf I.Priene 164-168), an altar for the joint cult of Poseidon Helikonios and Caesar Augustus (179), the boundary marker of a sanctuary (206: öpos i $\varepsilon \rho o \tilde{v}$, Hellenistic), an altar for the cult of a hero (210, Imperial period; cf. I.Priene 192),

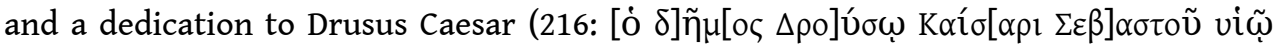
[i] $\varepsilon$ $\rho \omega \sigma \varepsilon v)$. Among the already known texts we mention the diagraphai concerning the sale of priesthoods (144 = I.Priene $174=L S A M 13 ; 145=E B G R 2012,211 ; 146=$ I.Priene $201=$ LSAM 38a; $147=$ I.Priene $202=$ LSAM 38b; $148=$ I.Priene 203), a cult regulation concerning the cult of the Egyptian gods (196 = I.Priene $195=$ LSAM 36), and a regulation forbidding the use of a fountain for purification $(377=E B G R 2012,85)$. The corpus also includes two inscriptions from the Panionion: a decree of the Iones concerning a verdict in a dispute about the priesthood of Zeus Boulaios and Hera (398 = I.Priene 139) and a regulation concerning the celebration of the Panionia (399; BE 1968, 469 and 1971, 582; not in LSAM). In an appendix, the editors collect the inscriptions of Thebai on Mykale, which include a cult regulation concerning the offerings of shepherds to Hermes (416 = I.Priene 362 = LSAM 39) [on this text see now W. MACK, "Shepherds Beating the Bounds? Territorial Identity at a Dependent Community (IPriene 361-363)", JHS (2015), p. 51-77].

23) P. BONNECHERE, “'Gouverner en toute sécurité'. L'oracle de Dodone et l'Athenaiôn Politeia, 43, 4", ZPE 189 (2014), p. 83-86: B. observes a striking similiarity between three oracular tablets from Dodona, (Lhôte, Lamelles oraculaires $\mathrm{n}^{\text {os }} 1-3$, 4 th cent.) with which cities ask the gods how they may achieve security, good government, and prosperity, and the manner in which these corncerns are formulated in a contemporary political treatise, Ath. Pol. 43.4. B. does not exclude the possibility that in that period Athens also sought the advice of oracles on public matters.

24) E. BoRgiA, "L'iscrizione di Athena en Tagais e i santuari rupestri della Cilicia Tracheia", Scienze dell'Antichità 17 (2011), p. 477-507 [SEG LXIII 1402]: B. presents a new critical edition of a decree from Seleukeia on the Kalykadnos (mid-2nd cent. CE) that concerns the purchase of the priesthood of Athena en Tagais by a certain Dionysodoros (cf. L. ROBERT, Hellenica III, Paris, 1946, p. 163-167). The decree begins with invocations

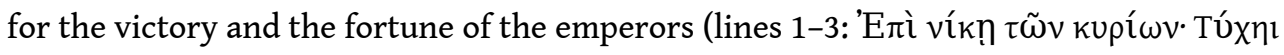

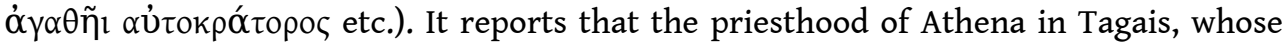
sale had been advertised for a sufficiently long period and which had been auctioned in

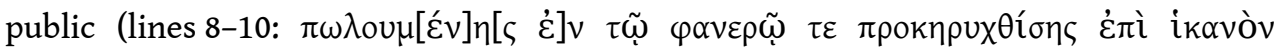
xpóvo[v]), was purchased by Dionysodoros. The wealthy man made the highest bid, offering 50 denarii for the construction of a rock-cut votive niche (tympanon) in which the decree was inscribed, and additionally making money donations to the council, the gerousia, and the people. He also covered the expense for various additional works: the

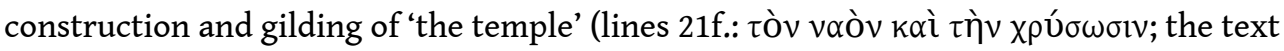
probably refers to the construction and decoration of the votive niche, rather than to the cult cave of the goddess), a gilded marble statue (lines $22 f .:$ ó $\gamma \alpha \lambda \mu \alpha$ $\pi \alpha \alpha_{\rho} i v o v$

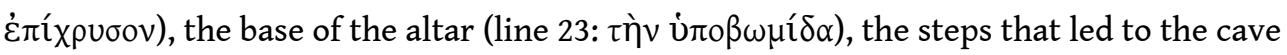
and a monumental door above the natural entrance of the cave (lines 23-25: $\tau \eta े v$

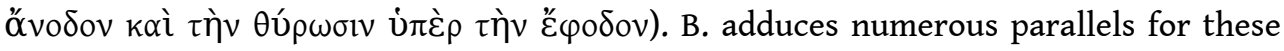


constructions as well as for cult caves in this area, dedicated to Zeus, Hermes, and Athena.

25) C. BRÉLAZ, Corpus des inscriptions grecques et latines de Philippes. Tome II. La colonie romaine. Partie 1. La vie publique de la colonie, Athens/Paris, 2014: The first fascicule of the long-awaited corpus of Philippi contains 225 inscriptions, mostly Latin, dating to the period of the Roman colony and concerning public life, in the broader sense of the word (i.e. honorific inscriptions, dedications, but also epitaphs that provide information on public life). Except for the texts that are marked with an asterisk, all the inscriptions had been included in Philippi $\mathrm{II}^{2}$. Only a few texts are in Greek. Dedications to: Genius Coloniae (43), Heros Aulonites (76, a thuribulum, an incense burner; cf. 158), Isis Regina (23), Iupiter Optimus Maximus (225, by a public slave), Mercurius Augustus (132), Quies Augusta Coloniae (84), Victoria Augusta (17), Victoria Germanica (25), and an anonymus god (81). Measurement tables were dedicated to Aeguitas Augusti (117) and Heros Aulonites (158). Associations: Honorific inscriptions

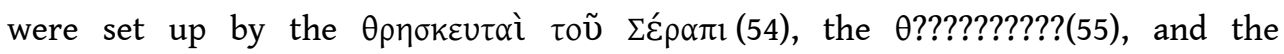

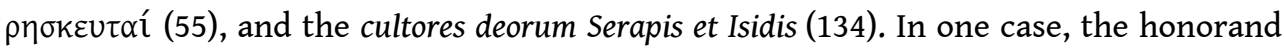
was son of an $\dot{\alpha}$ ???????? and served as ?????????? ??? ??????? ??????????, i.e. a contest

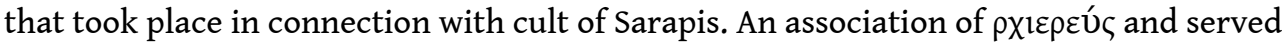

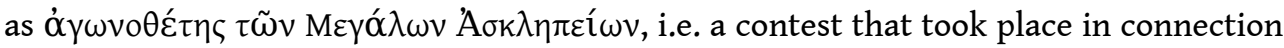
with cult of Sarapis. An association of cultores Cupidinis dedicated an epitaph (223). Cult personnel: There are references to priestesses of Deana Caszoria, i.e. Artemis Gazoria (135) and Isis (193), a pontifex $\left(184^{*}\right)$, and a sacerdos (225). Imperial cult: Evidence for the imperial cult is provided by an inscription that commemorates the dedications of the temple of the imperial cult (19) and dedications to Drusus (5), Claudius and his family (6), Vespasian and his sons (7), Trajan (10), Hadrian (11, 13), Hadrian Olympios and Sabina Iuno coniugalis (12), Antoninus Pius (14), the sons and grandsons of an emperor (15), Faustina Iunor (20), Septimius Severus and his family (24), Carinus (27), and unknown emperors $\left(33,34^{*}, 35\right)$. Numerous inscriptions mention the priests of the imperial cult (126: sacerdos divae Augustae), flamines of emperors $(6,53$, $\left.60^{*}, 62,66^{*}, 68^{*}, 69^{*}, 121^{*}, 127,130,151-153,154^{*}\right)$, and severi Augustales $(6,197-203$, $\left.204,205^{*}, 206-212,213^{*}-220^{*}, 221\right)$. Afterlife: A Latin epitaph for a woman ends with a greeting to the Thracian Rider God (4: Heroni salutem).

26) I. BULtRIGHINI, "Riflessioni su una dedica dei Lamptreis ad Apollo", RCCM 55 (2013), p. 29-44 [BE 2014, 158; SEG LXIII 160]: B. examines a dedication to Apollo (Lamptrai, Attica, mid-4th cent.; IG II ${ }^{2}$ 2967). She rejects the view of S.G. BYRNE ("The Dedication of

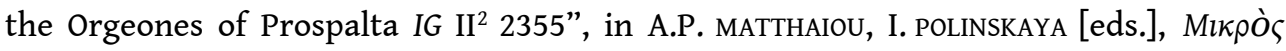

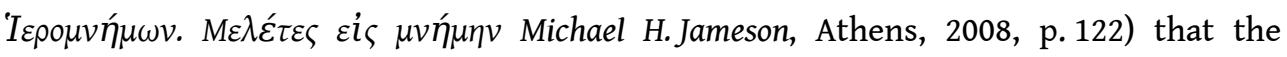
dedicants were orgeones. She also offers a new reading of line $1([\Lambda \alpha \mu] \pi \tau \rho \varepsilon \tilde{\tau} \varsigma \tau \tilde{\omega} l$ Aлó $\lambda \lambda \omega v \imath, \tau \tilde{\omega} \imath$

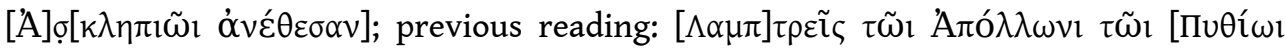
$\dot{\alpha} v \varepsilon \varepsilon_{\varepsilon \sigma \alpha v]}$ ) [her suggestion that this is a joint dedication to Apollo and Asklepios is rejected by C. FEYEL, BE 2014, 158, because of the absence of parallels].

27) I. BUltRighinI, “'Twin Inscriptions' from the Attic Deme of Myrrhinous”, ZPE 186 (2013), p. 141-151 [BE 2014, 144; SEG LXIII 169-170]: A certain Xenophon made two dedications in Myrrhinous, one to Zeus Phratrios as a memorial of his priesthood (SEG LIII $210=E B G R$ 2005, 146, ca. 400-350) and one to Apollo Pythios, in Apollo's sanctuary (SEG LVII 197). B. argues that both dedications stood next to each other in the same 
sanctuary [cf. EBGR 2005, 146], i.e., the sanctuary of Apollo Pythios (cf. SEG LIII 210:

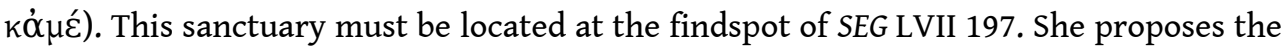

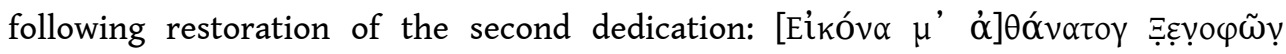

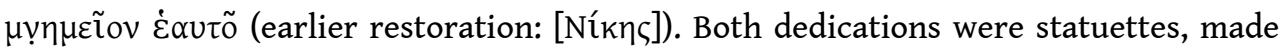

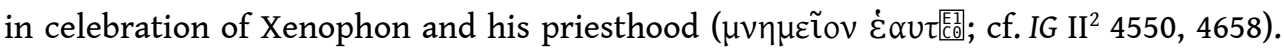
Images of cult personnel were dedicated on the Acropolis in the Classical period (late 5th-4th-cent.) [on the dedication of images of priests see infra $\mathrm{n}^{\text {os }} 95$ and 107].

28) P. CABANES, "L'hymne à Asklépios à Apollonie d'Illyrie", in D. LAURITZEN, M. TARDIEU (eds.), Le voyage des légendes. Hommages à Pierre Chuvin, Paris, 2013, p. 43-55 [SEG LXIII 407]: Ed. pr. of two very interesting inscribed lead tablets found in the agora of Apollonia. The first tablet (late 5th/early 4th cent.; p. 44-51) contains the third couplet of the paian for Asklepios, which is known from copies in Erythrai (I.Erythrai 205), Ptolemais (Inscr. métriques 176), Athens (IG II ${ }^{2} 4509+$ SEG XLVI 269), and Dion (SEG III 497) [see EBGR 2001, 62]. The text corresponds to that of the copies from Ptolemais and Dion. The tablet was probably a dedication to Asklepios, whose cult must have been brought to Apollonia by the Corinthian colonists (p. 44-51). C. interprets the second opisthographic tablet as a cult regulation approved by the oracle of Dodona. According to his restoration, the obverse concerns a prohibition concerning the cult of Asklepios, the reverse lists offerings to be made to various gods [better readings (especially of the reverse) and an excellent detailed analysis of the text are offered by J.-M. CARBON, S. PEELS, "Dossier of Regulations from Apollonia in Illyria", in CGRN n ${ }^{\circ} 40$. They interpret the text as a decree of Apollonia concerning religious matters. The obverse states that a female seer practiced cleromancy and determined that a certain action should not take place in connection with the cult of Asklepios ( $\Theta$ ??, ???? ?????? ?[?????]?? ???? ?????????[????]? ? ???????? ?À? ?????[?? ..] ????????? ??? ???[??]???? ???????? ???? [ca.?4] ??? ?[??]?????? ??[??-]). The better preserved reverse lists offerings to various gods: ??? ???[??]? ??????, ?????, ?????? [??? ?]???? ????, ???? ??[??]??? [..]???????? ????? ?????????? [ca.?5]?? ???????? ??[?]? ??????[? ca.?6] h??????[?]?? ?????? [ca.?8] ?????? [?]????? [ca.?8] ???[?]????; ?To Diona a vestment, a girdle, a pin. To Zeus Naios, an ox, three sheep. To [..]rranios (Zeus Tyrrhanios?), an ox. To Themis, [- -]. To Enyalios, [- - ] non-castrated male sheep. To the heroes, the gifts of hospitality. To NN, a goat. To Athena, [- -] female lambs?. Of the rest only remains of letters are preserved.

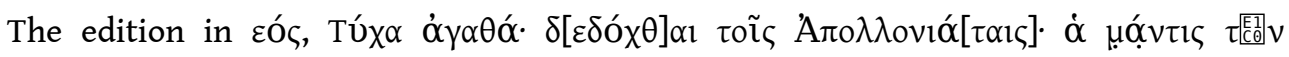

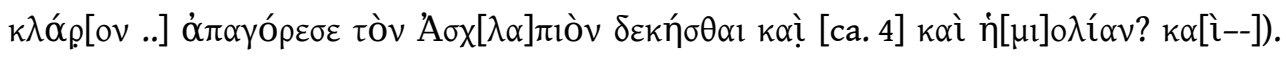

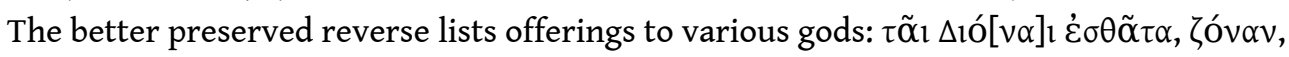

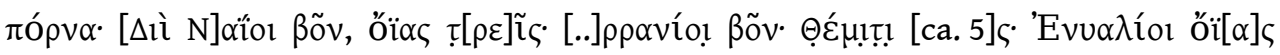

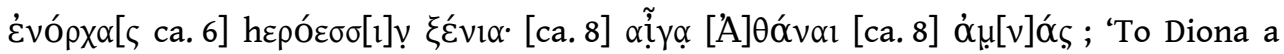
vestment, a girdle, a pin. To Zeus Naios, an ox, three sheep. To [..]rranios (Zeus Tyrrhanios?), an ox. To Themis, [- -]. To Enyalios, [- - non-castrated male sheep. To the heroes, the gifts of hospitality. To NN, a goat. To Athena, [- - ] female lambs'. Of the rest only remains of letters are preserved. The edition in CGRN clarifies the contents of the reverse and permits a better understanding of the text. As the eds. note, there is a striking connection with the oracle of Dodona, both in the use of cleromancy (see EBGR 2013,37 ) and in the list of gods (Dione, Zeus Naios, Themis). Also the interest in the cult of heroes corresponds to what one observes in the oracular tablets from Dodona (see EBGR 2013, 37). The mantis may indeed be a member of the cult personnel in Dodona. But the restoration of the text on the obverse poses problems, which are also 
recognized by the editors. After $\delta[\varepsilon \delta$ ó $\chi \theta] \alpha$ one expects an infinitive; here we have a

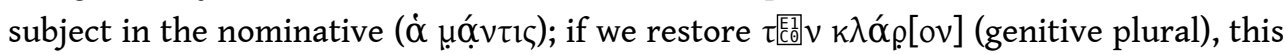
word lacks a syntactical connection; the solutions provided by eds. ('the seer of the lots', i.e., the interpreter of the lots, or genitive of cause) are not satisfactory. If we

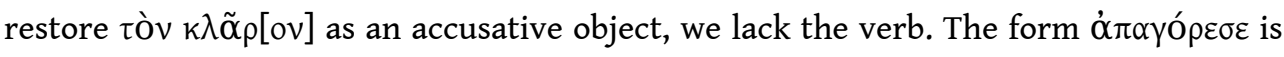
also hard to explain as a form of $\dot{\alpha} \pi \alpha \gamma o \rho \varepsilon v ́ \omega$, since one expects $\dot{\alpha} \pi \alpha \gamma o \rho \varepsilon \tilde{v} \sigma \alpha l$ or

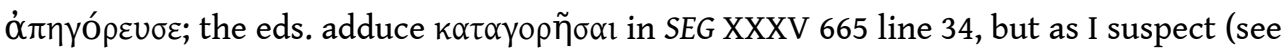

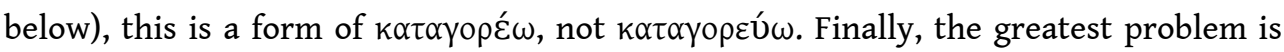
posed by the statement 'the female seer from the lots (drawn) forbids that Asclepius receives etc.'. What a seer can forbid is that people offer something, not that a god receives an offering. Given the fragmentary state of the text, I hesitantly attempt to

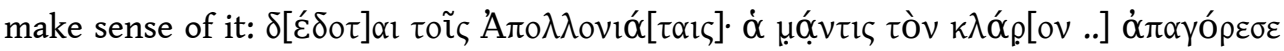

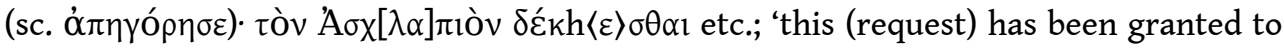
the Apolloniatia. The seer approved of the lot. May they receive Asklepios etc.' This restoration has obvious advantages: A new sentence starts with $\dot{\alpha} \mu$ póvviı; the coexistence of decree and oracle disappears; since in this text $\mathrm{H}$ always stands for the aspiration, the reading $\delta \varepsilon \varepsilon_{k h}\langle\varepsilon\rangle \sigma \theta \alpha l$ ( $\left.\delta \varepsilon \varepsilon_{\chi \varepsilon} \sigma \theta \alpha l\right)$ is certain. In my interpretation $\delta i \delta \omega \mu l$ does not refer to an oracle but to a request submitted by the Apolloniatai. Inquiries of

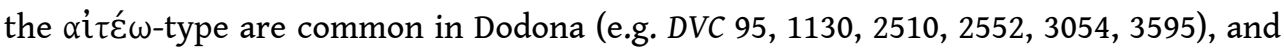
$\delta i \delta \omega \mu \mathrm{r}$ + dative is attested in the meaning 'to grant a request' (at least two certain

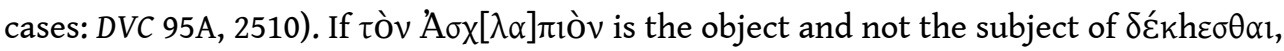
then the oracle recommends the introduction of his cult in Apollonia (cf. the formulaic

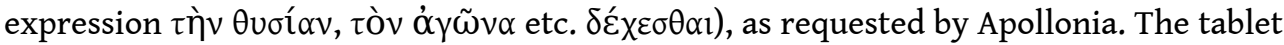
dates to the late 5th or early 4th cent., that is, the time in which Asklepios' cult is introduced to Athens. The introduction of a cult is one of the most common inquiries at Dodona. The only problem remains the meaning of $\dot{\alpha} \pi \alpha \gamma o ́ \rho \varepsilon \sigma \varepsilon$. I suspect that it is not a form of $\dot{\alpha} \pi \alpha \gamma о \rho \varepsilon v ́ \omega$ but the aorist of $\dot{\alpha} \pi \eta \gamma о \rho \varepsilon ́ \omega$. LSJ s.v. has $\dot{\alpha} \pi \alpha \gamma o \rho i ́ \alpha$, Doric for

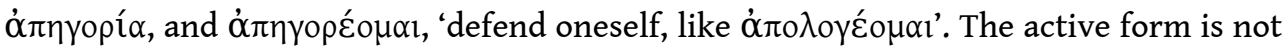

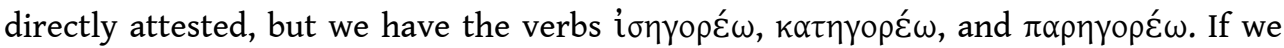
read $\dot{\alpha} \pi \alpha \gamma o ́ \rho \varepsilon \sigma \varepsilon$ for Attic $\dot{\alpha} \pi \eta \gamma o ́ \rho \eta \sigma \varepsilon$, the role of the seer was to approve of the lot that contained the oracular response, to free it from doubts, to account for it, to defend it. I am aware of the problems of this interpretation, but I hope that the continuous progress in understanding the oracular practice in Dodona will allow us to understand this text].

29) F. CAMiA, "Political Elite and Priestly Posts in Athens during the Roman Imperial Period: Some Considerations", ZPE 188 (2014), p. 139-148 [BE 2015, 233]: C. argues that in Athens a close connection between high political offices and priesthoods can only be observed in the case of the high-priesthood of the imperial cult [cf. infra $\mathrm{n}^{\circ} 36$ ]. This conclusion is based on a prosopographical study of members of elite families in Athens who held high offices and priesthoods.

30) B. CAPUZZA, "La lingua poetica degli oracoli di Klaros: l'oracolo clario da Kallipolis nel Chersoneso Tracico", EA 47 (2014), p. 21-52: C. republishes the oracle of Apollo Klarios for Kallipolis (I.Sestos 11) with Italian translation and detailed philological commentary. The oracle prescribes ritual actions (sacrifice, libation, erection of Apollo's statue) through which Apollo would save the city from disease. The analysis of metre and language supports the conclusion that the poetic language of the Klarian oracles follows the tradition of Hellenistic poetry. 
156 31) J.-M. CARBON, "Dated Sacrifices in the Gymnasion at Kadiköy”, EA 47 (2014), 147-148: C. presents an improved edition of the last lines of a decree from Apollonia on the Maeander in Lydia in honor of the benefactor Asklepiades of Pergamon (SEG XLIX 1540; republished by N. KAYE, R. SOUZA, "New Readings of the Decree for Asklepiades son of

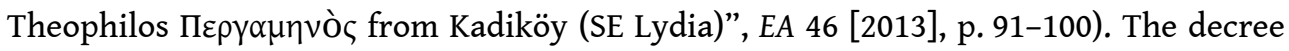

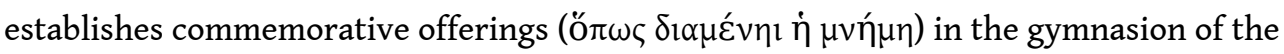
neoi that took place on several occasions during the year. C. argues that here $\dot{\varepsilon} \pi \theta u ́ \omega$ does not necessarily designate the offering of incense but possibly refers to a complementary sacrifice.

157 32) J.-M. CARBon, “A Hellenistic Ritual Calendar from Kyzikos”, EA 47 (2014), p. 149-155 [BE 2015, 597]: C. presents an improved edition of a fragmentary decree from Kyzikos (4th/3rd cent.; M. тнеотікоU, "Ein unpublizierter Ratsbeschluß aus Kyzikos", EA 44 [2011], p. 133-141; SEG LXI 1026; cf. P. HAMON, BE 2012, 348; never presented in EBGR). According to his restorations, the purpose of the decree was the proper performance of

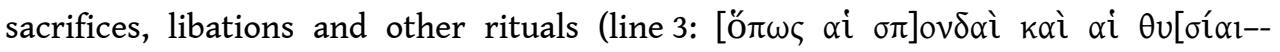

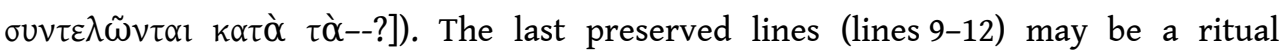
calendar starting with the month Anthesterion (line 9); this is puzzling, since the year in Kyzikos is known to have started with Taureon (at least in the Imperial period). The rituals in this month start with the purification of the city (line 10: $\pi$ ó $\left.\lambda_{1 \varsigma} \kappa \alpha \theta \alpha i ́ \rho \varepsilon \tau[\alpha 1]\right)$; then, the text mentions the sacrifice of a pig to [Hestia Pry]taneia (line 11) [the sacrifice of a pig to the patron goddess of the council's hearth may be part of the purification of the city].

158 33) A. ChANIOTIS, "Roman Army in Aphrodisias", Revue des Études Militaires Anciennes 6 (2013), p. 151-158 [BE 2014, 428; SEG LXIII 858]: Ed. pr. of a sarcophagus from Aphrodisias (ca. 220-230). The epitaph threatens any violator of the grave that he will be 'be impious and accursed and a tomb robber and will pay, in addition to this, to the Goddess Aphrodite 2,000 silver denarii and to the centurion at the site 1,000 denarii'

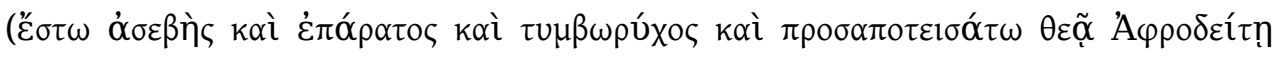

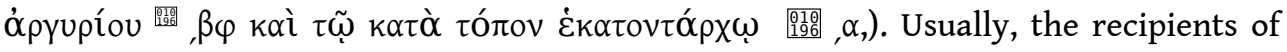
fines for violations of the grave were the fiscus, the sanctuary of Aphrodite, the imperial cult, and professional associations; the payment to a Roman officer is unique.

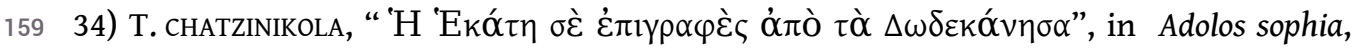
p. 127-144: C. collects epigraphic evidence for the cult of Hekate in the Dodecannese (Rhodes, Kos, Chalke). Her properties as a protective divinity are revealed through her association in inscriptions with other deities (Kamiros: Hermes Propylaios, Apollo Apotropaios; Chalke: Zeus) as well as through her epithets (Kamiros: Propylaia; Rhodes: Ennodia, Phosphoros, Euekoos; Kos: Stratia, Meliteina, Soteira, Pontia).

160 35) A.M. CIRIO, Gli epigrammi di Giulia Balbilla (ricordi di una dama di corte) e altri testi al femminile sul colosso di Memnone, Lecce, 2011 [SEG LXI 1537]: C. presents a new critical edition of the epigrams composed by Sabina's friend Iulia Balbilla on the occasion of Hadrian's visit to the Colossus of Memnon (Thebes, Egypt, 130 CE; I.Col.Memnon 28-31). C. discusses the cult of Memnon, the acoustic phenomenon that attracted visitors, and the religious background of Hadrian's visit, and comments in detail on Balbilla's poetry and family.

161 36) K. CLINTON, "The Inscriptions and the Sanctuary of the two Goddesses at Eleusis", in

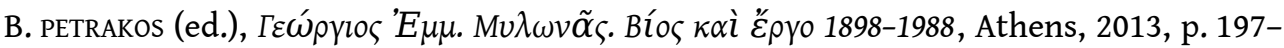


204 [SEG LXIII 30]: On the basis of I.Eleusis 177 lines 6-8 (330/329 BCE), C. argues that the delivery of the first fruits ('ं $\pi \alpha \rho x \alpha i)$ lasted for about 61 days (ca. 4 Thargelion to 6 Hekatombaion); this suggests a large number of donors, both demes and private individuals. Documents pertaining to the early imperial cult in Athens (I.Eleusis 297: Augustus; 334-336: Tiberius and Livia; 354: Agrippina the Younger and Nero; 361: the $\Sigma \varepsilon \beta \alpha \sigma \tau o i)$ show that the priests were members of the prominent Eleusinian gene of the Kerykes and the Eumolpidai, which enthusiastically adopted the imperial cult [cf. supra $\left.\mathrm{n}^{\circ} 29\right]$.

37) R. CRIBIORE, P. DAVoli, D.M. RATZAN, “A Teacher's Dipinto from Trimithis (Dakhleh Oasis)", JRA 21 (2008), p. 170-191 [SEG LXI 1810]: Ed. pr. of an interesting dipinto on the plaster of a wall of a room at Trimithis in Egypt (ca. 340-360 CE). The text consists of didactic epigrams that encourage young men to dedicate themselves to the study of

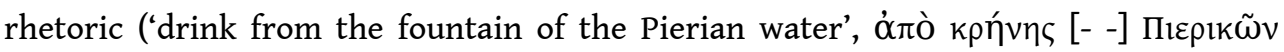

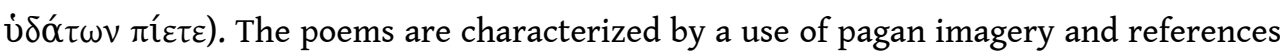
to mythical figures and Greek gods (Hermes, Maia, Muses, Charites, Herakles, and a

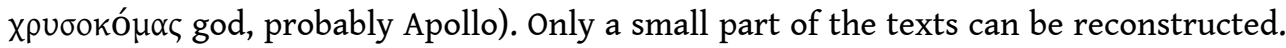
One of the best preserved passages reads: "Here (I withdraw), near the sources of the sacred leaves. But may god grant my wishes that [you all] learn the Muses' honeyed works, with all the Graces and with Hermes son of Maia reaching the full summit of rhetorical knowledge. Be bold, my boys: the great god will grant you to have a beautiful

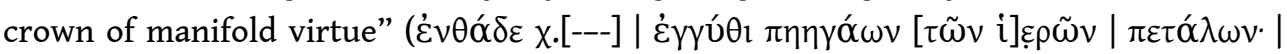

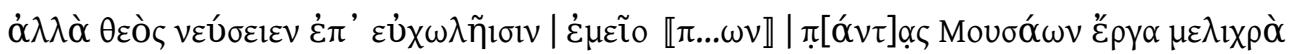

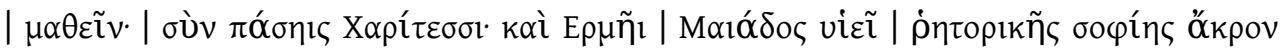

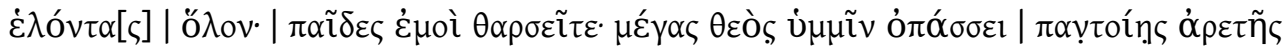

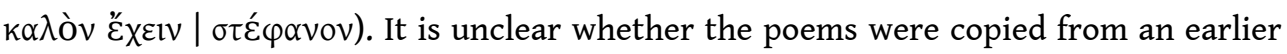
collection or were composed by a local teacher. Despite the references to gods and a

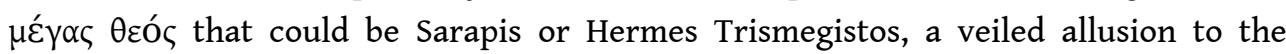
Christian god cannot be excluded.

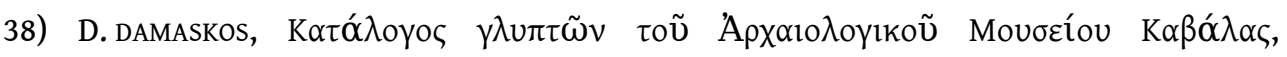
Thessaloniki, 2013: Ed. pr. of the statuette of an eagle of unknown provenance in Thrace (1st/2nd cent.); a Latin inscription reports that it was dedicated to Iupiter (Jovi) by M. Vesonius Stephanus [to judge from the votive object (cf. EBGR 1993/94, 42), the addressee is Zeus Hypsistos]. The dedicant is known from his epitaph found in Philippi (Philippi $\mathrm{II}^{2}$ no 154).

164 39) D. DANA, "Possibles témoignages sur des cultes daces: la documentation épigraphique de la Mésie Inférieure", in M. TAUFER (ed.), Squardi interdisciplinari sulla religiosità dei Geto-Daci, Freiburg, 2013, p. 157-176 [BE 2014, 289; SEG LXIII 516]: D. recognizes Dacian and Daco-Moesian names in dedications from Moesia Inferior. This onomastic material allows D. to recognize Dacian cults in these dedications. He

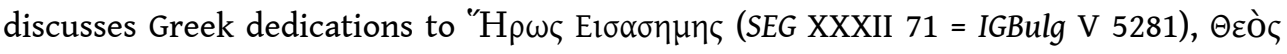

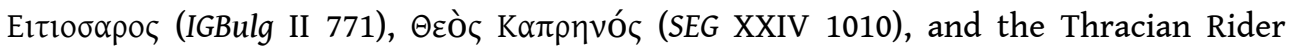
(IGBulg V 5269 and 5319).

40) D. DANA, "Notices épigraphiques et onomastiques I", ZPE 188 (2014), p. 181-198: D. republishes a dedication of unknown provenance offered by the auction's house Herrman Historica (Auktion 65, 15-16 October, 2012) $\mathrm{n}^{\circ} 339$. It is a relief plaque with Zeus offering a libation (2nd/3rd cent.). The relief was dedicated by Deineilas, son of Drales, 
to Zeus in fulfilment of a vow (ع????). The names suggest a provenance from Thrace (188f.). D. republishes an intaglio of unknown provenance, now in the Hermitage, with an invocation of Sarapis (R.?ủxńv). The names suggest a provenance from Thrace (188f.). D. republishes an intaglio of unknown provenance, now in the Hermitage, with an invocation of Sarapis (R. VEYMIERS, "I $\lambda \varepsilon \omega \varsigma \tau \tilde{\omega}$ opoũv $\tau$. Sérapis sur les gemmes et les

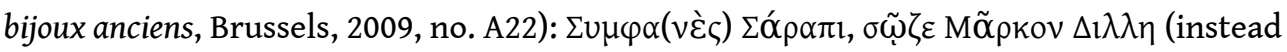
of $\Sigma v \mu \varphi \tilde{\alpha}) . \Sigma v \mu \varphi \alpha v \eta ́ \zeta$ is an epithet of Sarapis; Dilles a Thracian name.

41) F. D'ANDRIA, “Il Ploutonion a Hierapolis di Frigia”, MDAI(I) 63 (2013), p. 157-217 [SEG LXIII 122]: One of the most interesting archaeological discoveries in Roman Asia Minor is the identification of the sanctuary of Plouton in Hierapolis. The identification is confirmed through the discovery of a dedicatory inscription that reports that an anonymous donor dedicated an arch ( $\psi \alpha \lambda i \mathbf{i}_{\zeta}$, the vaulted entrance to the cave of the Ploutonion) to Plouton and Kore (1st cent. CE).

42) R. DESCAT, “Toujours I.Mylasa 11 : autorité et territoire dans la Carie hékatomnide”, EA 47 (2014), p. 53-72: See infra ${ }^{\circ} 132$.

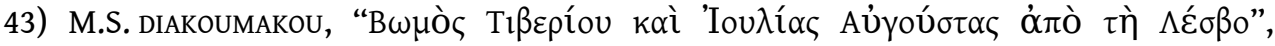
Grammateion 3 (2014), p. 7-10: Ed. pr. of an inscribed altar for the cult of Tiberius and Livia ( $\Theta \varepsilon \grave{\alpha} \Sigma \varepsilon \beta \alpha \sigma \tau \alpha ́)$ from Lesbos (ca. 14-29 CE). The altar was dedicated as an

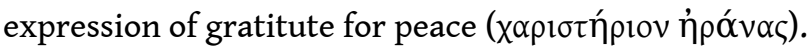

44) F. DÖNMEZ ÖZTÜRK, “New Votive Inscriptions from Nikaia”, Cedrus 1 (2013), p. 285-292 [BE 2014, 478; SEG LXIII 1137-1141]: Ed. pr. of dedications from the territory of Nikaia (Imperial period). Dedications to Theos Agathos (1; cf. SEG LIV 1486-1487; possibly an epithet of Zeus), Zeus Ouebreanos (2; unattested epithet deriving from a place name), Zeus Soter (3; a thanks-giving dedication: xó $\rho ı v)$, Zeus Bronton (4), and Zeus (5, an altar dedicated in fulfilment of a vow: $\dot{\varepsilon} \xi \varepsilon \dot{U} \chi \tilde{\eta} \varsigma)$. Almost all of the dedications start with the invocation Ay $\alpha \theta \tilde{n} \tau \dot{\chi} \chi \underline{n}(1-3,5)$. The dedication to Zeus Soter was made by a man, probably a freedman, for his patrons in fulfilment of a vow (3: $\dot{v} \pi \dot{\varepsilon} \rho \tau \tilde{\eta} \varsigma \tau \tilde{\omega} \nu \pi \alpha \tau \rho \omega ́ v \omega \nu$ iऽ $\alpha i \tilde{\omega} v \alpha \delta i \alpha \mu o v \tilde{\eta} \varsigma)$.

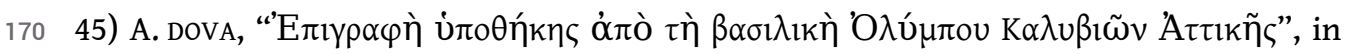

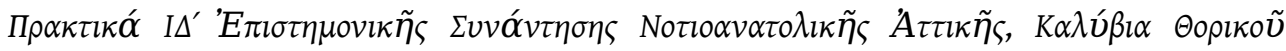

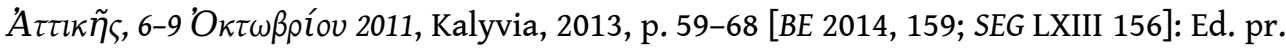
of a security horos of a mortgaged piece of land and a house belonging to the deme of Myrrinous (Athens, ca.350-300); the loan had been given from sacred money of

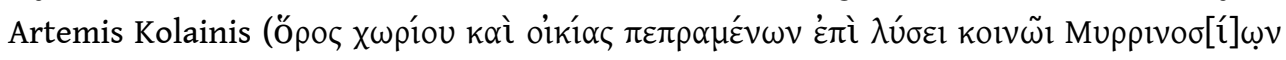

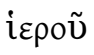

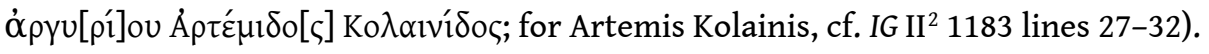

46) L. DUBoIs, "Une inscription sicilienne déconcertante", REG 126 (2013), p. 1-19: D. republishes and discusses an enigmatic honorific decree preserved in two copies on two bronze tablets from Halaisa (EBGR 2010, 116 and 177). The decree, dated by a reference to the priest of Zeus and the two priests of Apollo, is written in the Rhodian dialect. It honors a certain Nemenios for his benevolence and benefactions towards the 'priests of Apollo' and the 'koinon of the priests of Apollo'. The text has the form of a civic decree but with puzzling peculiarities, apart from the double eponymous priesthood. It is presented as a decree of an assembly (halia) and a council, consisting of 15 members

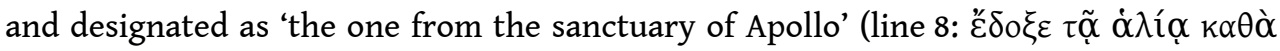

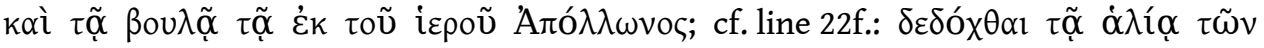




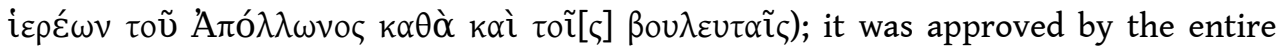
koinon with 825 votes. The only parallel for a Korvòv $\tau \tilde{\omega} v$ i $\varepsilon \rho \varepsilon \varepsilon \omega v$ is found in another inscription from Halaiasa (IG XIV 354 lines 3/4). The number of 825 priests is hard to explain. Could the number of votes refer to the votes in the assembly by which a decree of an association of priests was ratified?

47) K.M.D. DUNBABIN, "Domestic Dionysus? Telete in Mosaics from Zeugma and the Late Roman Near East", JRA 21 (2008), p. 193-224 [SEG LVIII 1855, 1915]: D. examines the presence of Dionysiac themes in mosaics from the Roman Near East and the connection between Dionysiac images, myths, and cult. She focuses in particular on mosaics with

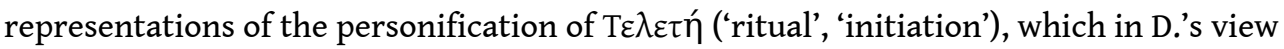
does not refer to specific rituals but alludes, very generally, to Dionysiac revelry. She discusses a mosaic from Syria or Arabia (ca. 150-220 CE) that shows the wedding of

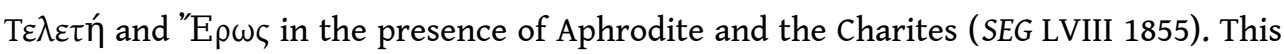
subject, possibly peculiar to Syria, is connected with the idea that marriage is an initiation into the mysteries of love (cf. Menander Rhetor 2.7).

48) B. EмME, "Kein Kaiserkult. Rekonstruktion und Deutung der 'ara augusti' im Buleuterion von Milet", MDAI(I) 64 (2014), p. 163-178: The remains of a monument in the court of the Bouleuterion of Milet had been interpreted as an altar for the Imperial cult. Neither the architectural remains nor an epigraphic find (Milet VI.1.6) support this conclusion. The inscription is a dedication (cf. $\kappa \alpha \theta \varepsilon \hat{\varepsilon} \rho \omega \sigma \varepsilon v)$ in honor of the heroized (cf. n̆ $\rho \omega \imath$ ) C. Iulius Epikrates, priest of the imperial cult. If the inscription belonged to the monument, it seems to have been an 'honorary tomb'.

49) H. engelmann, C. IçTen, U. muss, "Künstler im Artemision von Ephesos", ZPE 191 (2014), p. 99-116 [BE 2015, 59]: The authors present inscribed bases of statues dedicated by the neopoiai in the Artemision of Ephesos. Except for $n^{\circ} 3$ (SEG XLV 1584), the other texts are inedita. The bases supported statues, three of which were works of the famous sculptor Alkamenes (1-3, late 5th cent.). Three statues were signed by Eugnotos (4, ca. 400) and Sopolis (6-7, ca. 350), and another three were not signed (5, ca. 425-375; 89 , late 4 th cent.). The earliest of these inscriptions (1-2) are the earliest attestations of the board of the neopoiai. The new inscriptions are important testimonia for the decoration of the sanctuary with marble statues from the late 5 th to the late 4 th cent.

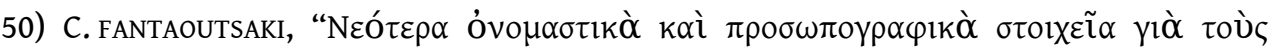

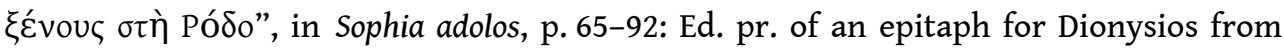
Antioch, who died as a metic in Rhodes (1st cent.), and members of his family. The interesting text mentions his services to the city and the honors that he and his father had received. Both he and his father had served as choregoi and had been honored with

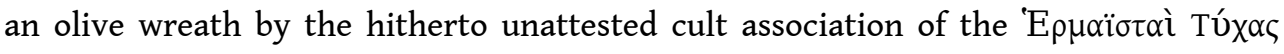
A $\gamma \alpha \theta \tilde{\alpha} \varsigma$ 'O $\lambda u \mu \pi \varepsilon i ́ \omega v$ Eỉ $\delta \propto \mu o ́ v \omega v$. This cult association, primarily dedicated to the worship of Hermes, combined Hermes' cult with that of Tyche Agathe and the 'Blissful Olympians', i.e. all the Olympian major and minor gods. Dionysios was additionally

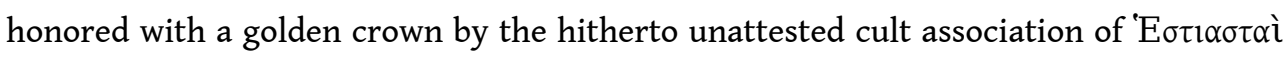

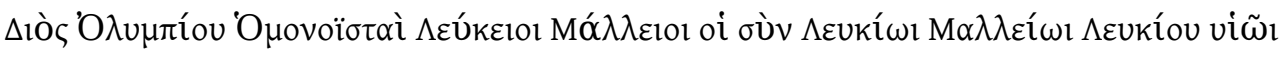

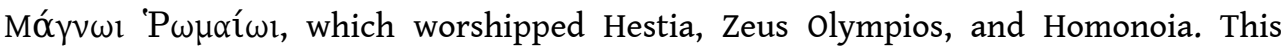
association had been founded or re-founded by Lucius Mallius; his son Lucius Mallius Magnus served as its chairman [more probably, the founder and the current chairman

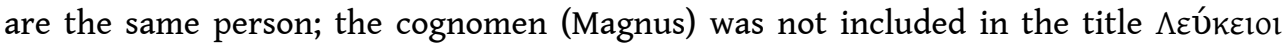
Mó $\left.\lambda \lambda \varepsilon_{\varepsilon 101}\right]$. The gods worshipped by this association seem to correspond to Vesta, 
Iuppiter, and Concordia, and therefore reveal Roman influence. This text provides important evidence for the coming together of metics of various origins in the same association.

51) M. FARACE, "Il santuario di Apollo Hyperteleatas", Epigraphica 75 (2013), p. 33-43: F. gives an overview of the dedications found in the sanctuary of Apollo Hyperteleatas in the peninsula of Parnon in Lakonia (cf. Paus. 3.22.10), mainly bronze objects. He distinguishes three main periods: late 7th-late 4th cent.; late Hellenistic (2nd cent.ca. $25 \mathrm{BC}$ ), and Imperial period. A study of the objects and their inscriptions (IG VI. 1.931-932, 961-967, 975-1106; cf. SEG XI 907; XXXII 390) show that the sanctuary was visited by people of high rank; an inscription on a perirhanterion (?) suggests contacts with Kyrene ( $L S A G^{2} 201$ no 43).

52) J.-L. FERRARY, Les mémoriaux de délégations du sanctuaire oraculaire de Claros d'après la documentation conservée dans le Fonds Louis Robert, Paris, 2014 [BE 2015, 611]: The two volumes of this long awaited corpus contain ca. 420 inscriptions that commemorate the

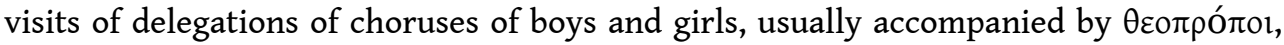
cult officials and other city representatives, to the sanctuary of Apollo Klarios. F. publishes the texts with exhaustive discussion of the history of research, the areas of the sanctuary where the texts were written (propylaia, sacred road, temple of Apollo, area of altars), the onomastics, the prosopography, the administration and the cult personnel of the sanctuary (priest, thespiodos, prophetes, scribe), the practice of honoring Apollo through choruses and hymnody, and the cities that sent delegations to the oracle. The texts provide valuable information on the individuals who held offices at Klaros from ca. 105 to ca. $236 \mathrm{CE}$; they also show that the office of the eponymous prytanis at Kolophon was held 150 times by Apollo (p. 74-108). The cities which dispatched choruses were mainly cities of the province of Asia, some of which regularly sent a delegation; the record is held by Laodikeia on Lykos, which sent delegations 4547 times (cf. Herakleia Salbake: 31; Chios: ca. 36-40; Phokaia: ca. 25-35). Other regular participants include Aphrodisias, Tabai, Akmonia, Ikonion, and Amaseia. However, most cities (29 out of 51) are represented by only one single commemoration. Outside of Asia, there were numerous delegations from Crete (20-24 cases from Hierapytna, Lappa, and Kydonia), and rare visits of delegations from Achaia (1 case: Corinth), Macedonia ( 3 cases: Charax, Stobi, Macedonian Koinon), Thrace ( 8 or 9 cases: Perinthos, Thasos, Plotinopolis, Markianopolis, Hadrianopolis, Ainos, Deultum, Philippopolis), and the west and north shores of the Black Sea ( $4-5$ cases: Chersonesos in Tauris, Olbia, Dionysopolis, Odessos). Some of the cities that sent delegations are known to have received Klarian oracles (p. 110-114). In the case of Bargasa $(2,6,10,12)$, Laodikeia (27, $31,34,63)$, Perinthos (11), Thasos (30), and anonymous cities $(6,365)$ it is explicitly

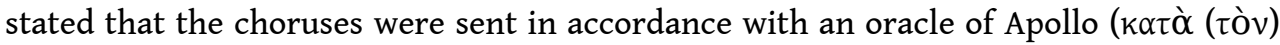

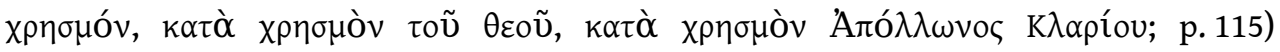
[interestingly, these references are to be found only in the early records (ca.105$141 \mathrm{CE})$ ]. Some of the texts mention additional reasons for the visit of delegations (e.g., 191: dedication of three silver images by Kaisareia Germanike $\dot{u} \pi \dot{\varepsilon} \rho \tau \tilde{\eta} \varsigma \dot{\varepsilon} \alpha u \tau \tilde{\omega} v$

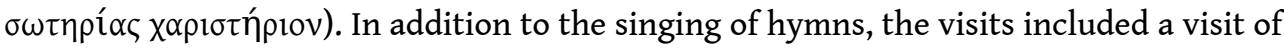

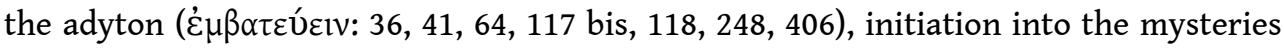

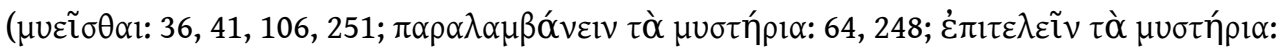
154 bis, 173, 174, 176, 293, 308, 318, 402, 415), and consultation of the oracle (p. 115-

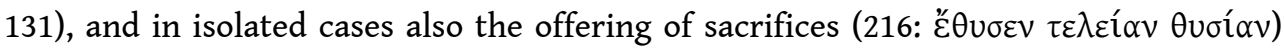


and votives (191) [note that the dedication of three silver images was connected with a

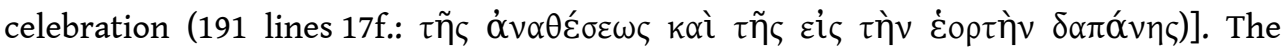

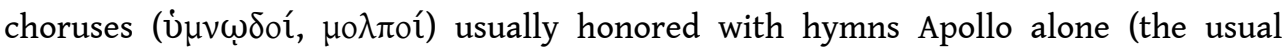

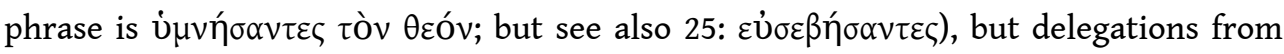
Bargasa $(2,10,12)$, Chios $(23)$, Laodikeia $(63,101,107)$, and an undetermined city $(364)$

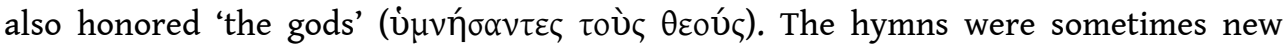
compositions $(11,31,78)$. We note the presence of ephebes in the delegations, especially the later ones $(29,282,285,291,292,306,311-316,402)$. The texts provide also information about the religious institutions of the cities that dispatched the choruses: the $\dot{\alpha} \rho x 1 \theta \varepsilon \eta \kappa o ́ \lambda \circ \varsigma$, a hitherto unattested office, possibly in Hierapytna (338), the i $\varepsilon \rho \varepsilon \grave{u} \varsigma$ $\pi \alpha i \delta \omega v$ in Herakleia Salabake $(88,116,136,161,162,187,188,215,253,304$, 316, 317), Aphrodisas (142), Tabai (131), and Laodikeia (209, 223, 247, 287), the

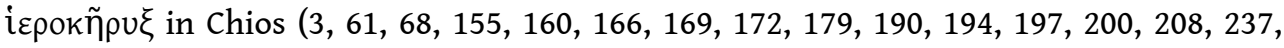

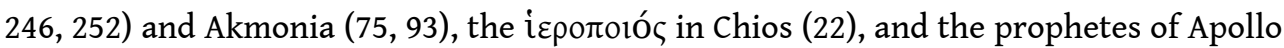
Pythios $(27,31,134$, etc.) and agonothetes of the Dia Kleoxeneia in Laodikeia (209, 223, $247,281,283,287,289,290,348)$. Among several inscriptions that attest the accumulations of offices, we single out the case of C. [-]mos Flaccus in Laodikeia (287), who served as prophetes of Apollo Pythios, priest of the boys, and agonothetes of the Dia Kleoxenia. Despite the formulaic character of most texts, one notices individual

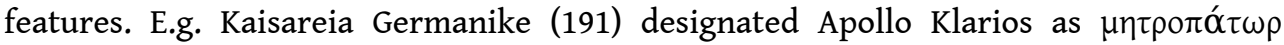
(maternal grandfather), probably because it was a colony of Myrleia, which in its turn was a colony of Kolophon. This corpus is an important contribution to the study of religious practices in the 2nd and 3rd cent. CE, especially the importance of hymnody.

53) P. FIGUERAS, The Pagan Image of Greco-Roman Palestine and Surrounding Lands, Oxford, 2013 [SEG LXIII 1543, 1549, 1579-1581, 1585-1588]: This survey of archaeological evidence for 'paganism' in Palestine and Judaea, contains numerous references to inscriptions of religious interest, mostly published texts. We present the inedita and a selection of interesting texts; for some of them we use the texts read by M. ZellmannRohrer in SEG LXIII $(1549,1579,1580)$. Berosaba-Beer Sheba: A Hellenistic medallion with

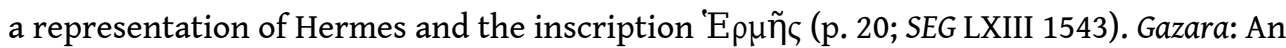
altar of Herakles and an anonymous god (Hellenistic; mentioned without text by R.A.S. MACALISTER, Bible Side-Lights from the Mound of Gezer. A Record of Excavation and Discovery in

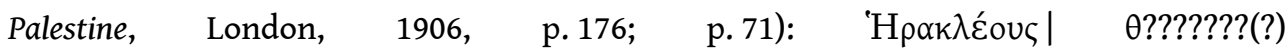
????? ???????| ?????????| ????? ????????????. Z.-R. mentions as a possible parallel the

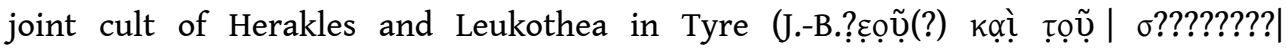
????? ????????????. Z.-R. mentions as a possible parallel the joint cult of Herakles and Leukothea in Tyre (J.-B.?ụvvóou| $\theta$ ???? ????????????. Z.-R. mentions as a possible

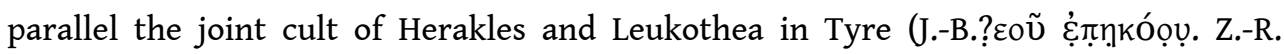
mentions as a possible parallel the joint cult of Herakles and Leukothea in Tyre (J.-B. YON, J. ALIQUOT, Inscriptions grecques et latines du Musée national de Beyrouth, Beirut, 2016, $\mathrm{n}^{\circ}$ 310). Mt. Gerizim: An inscription on a sundial (2nd cent.) reports that it was dedicated to Theos Hypsistos by a Ptolemaic functionary (mentioned by Y. MAGEN, Mount Gerizim Excavations, Volume II. A. Temple City, Jerusalem, 2008, p. 156; p. 69) and two dedications to Zeus Olympios (p. 70; SEG LXIII 1580-1581; Imperial period and 4th cent. CE). Sebaste-

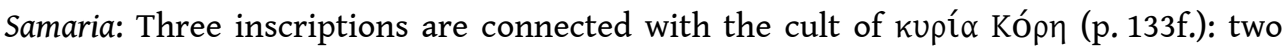

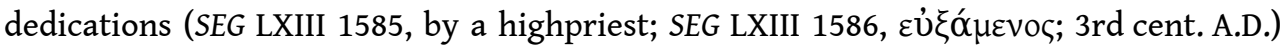
and an interesting acclamation written with red paint on a plaque found in a cistern; 
the acclamation praises 'the one god, the ruler of all' and 'great Kore, the invincible

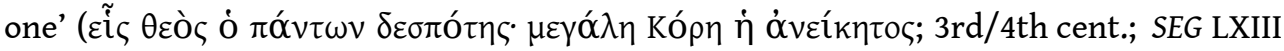

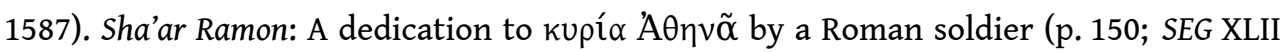
1455; LXIII 1588; 2nd/3rd cent.).

54) J. FOURNIER, S. DADAKI, "Hérodès fils de Samos et sa famille. Autour d'une inscription funéraire en remploi dans la basilique Nord du site d'Hagios Vassileios (Thasos)", BCH 136/137 (2012/13), p. 269-298 [SEG LXIII 721]: The discovery of an epitaph for Herodes, son of Samos, and another four members of his family give the opportunity to the authors to study a prominent Thasian family of the imperial period. Its members include dedicants (IG XII.8.379: Samos, son of Herodes, and Herodes, son of Samos, 1st cent.) and an anthophoros (IG XII Suppl. 410: Perigenis, daughter of Herodes, 2nd cent. $\mathrm{CE}$ ).

55) P. FUNKE, K. HALLOF, "Zwei neue Staatsverträge aus Akarnanien", in Forschungen in Akarnanien, p. 55-64 [BE 2014, 254; SEG LXIII 391]: Ed. pr. of two fragmentary treaties preserved on an opisthographic stele from Akarnania: a treaty of alliance between Anaktorion and another partner (late 5th/early 4th cent.) and treaty between Akarnanians, Amphilochians, and Ambrakiotai (late 4th cent.). Only parts of the two treaty oaths are preserved. In the first oath one recognizes an imprecation formula

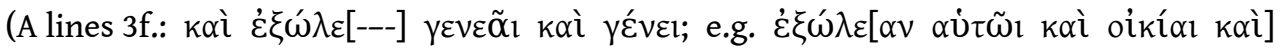

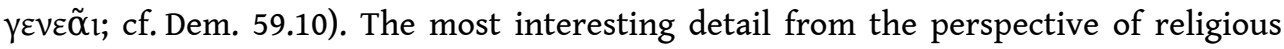

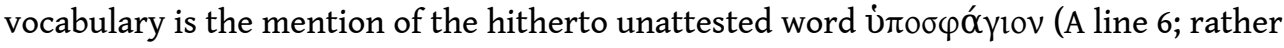
than ن்

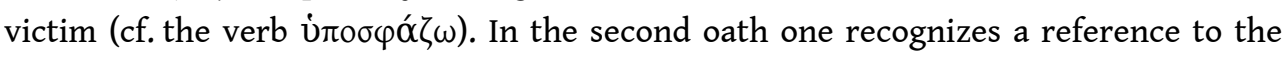

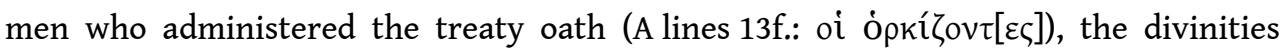

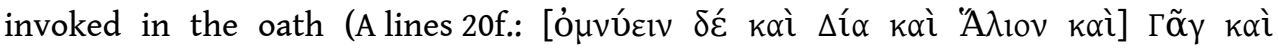

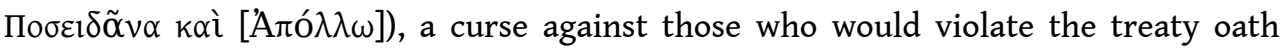

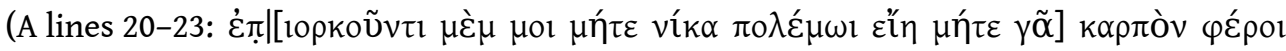
$\mu \eta \tilde{\tau \varepsilon}[\theta \alpha \dot{\alpha} \lambda \alpha \sigma \sigma \alpha--$-]), and possibly a reference to the olympic festival (A line 26:

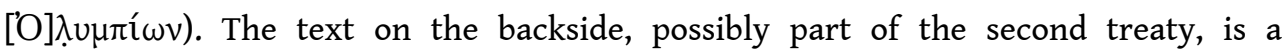
delimitation; a sanctuary of Aphrodite is mentioned as an orientation point (B line 7:

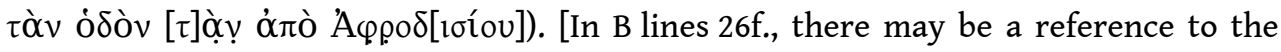

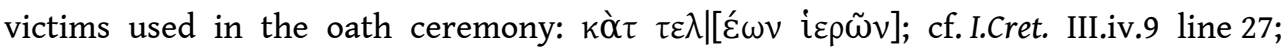

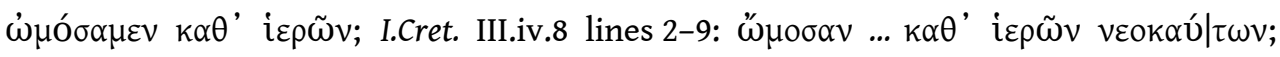
further examples of $\kappa \alpha \theta$ ' i $\varepsilon \rho \tilde{\omega} v$ : IG XII.4.132 lines 127/128; SEG XXIII 547 line 15; XXXII 1097 line 6; I.Labraunda 6 line 11].

181 56) J.L. GARCIA RAMÓN, B. HELLY, “Deux nouvelles épiclèses de la déesse En(n)odia dans des inscriptions de Larisa", in A. BLANC et alii (eds.), ПОАYMHTIL. Mélanges en l'honneur de Françoise Bader, Louvain/Paris, 2012, p. 41-53 [BE 2013, 238; SEG LXII 372]: The authors discuss the meaning of two epithets of Ennodia in Thessaly. In the dedication SEG LIV 561, the epithet of Ennodia is $\Sigma \tau \rho o \pi ı k \alpha ́$ (not $\Sigma \tau \rho o \gamma \imath k \alpha ́$ ). This epithet derives from

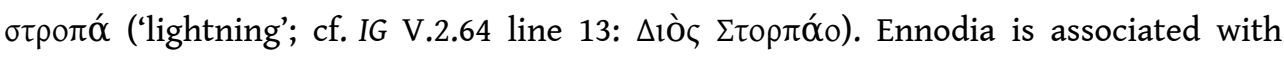

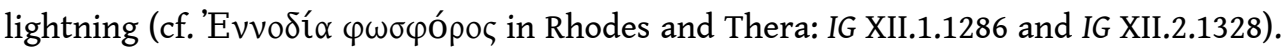
The epithet Mukä̈кó (F. SALVIAT , C. VATIN, Inscriptions de Grèce centrale, Paris, 1971, no. 9.1 line 28) derives from $\mu$ úkn, 'tomb'. Ennodia was regarded as protector of tombs.

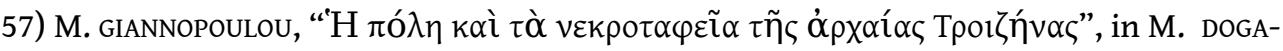

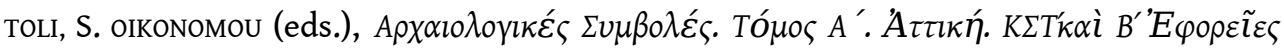




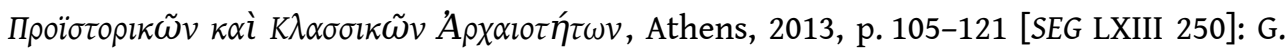
mentions the discovery of a lead weight at a site on the road from Troizen to Hermione

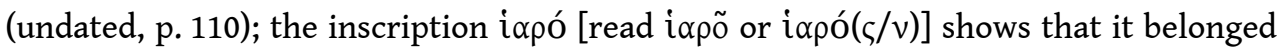
to a sanctuary near Troizen, probably that of Apollo Platanistios (cf. Paus. 2.34.6).

58) C. GRAML, "Hekate as a Product of the 19th Century", Jahrbuch der Berliner Museen 55 (2013), p. 13-17 [SEG LXIII 63]: After careful examination of the graffito $\theta \dot{\varepsilon} \kappa o ́$ ¿El on an inscribed figurine from Athens (IG I ${ }^{2} 836$, late 6th/early 5th cent.), believed to be the earliest representation of Hekate, G. concludes that the reading is uncertain and that the text probably is a 19th century-forgery.

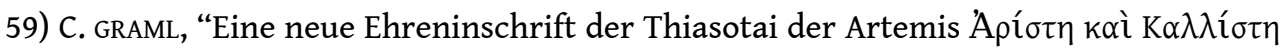
aus dem Athener Kerameikos", ZPE 190 (2014), p. 116-126 [BE 2015, 219]: Ed. pr. of an honorific inscription from Athens (3rd cent.). It was set up by a cult association

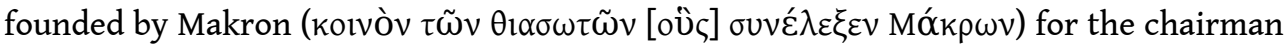

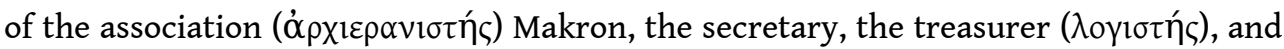
the board of three supervisors ( $\sigma \cup v \varepsilon \pi \imath \mu \varepsilon \lambda \eta \tau \alpha$ ). The context of the discovery near the Dipylon Gate suggests that the association was that of worshippers of Artemis Ariste and Kalliste, known from other inscriptions (IG $\mathrm{II}^{2}$ 1297-1298). Her sanctuary is mentioned by Pausanias (1.29.2) [cf. infra $\mathrm{n}^{\circ}$ 77].

60) Y. GRANDJEAN, "Inscriptions de Thasos", BCH 136/137 (2012/13), p. 225-268 [SEG LXIII 716-719]: Ed. pr. of inscriptions from Thasos. 1) The board of the apologoi made a

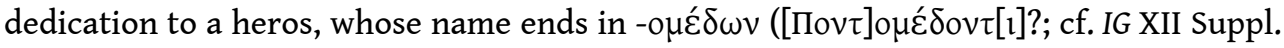
431: Поvто[- -]; 3rd cent.; p. 252-254 n ${ }^{\circ}$ 6). 2) Dedication to Aphrodite by the board of three gynaikonomoi (254f. $\mathrm{n}^{\circ} 7$; 3rd cent.). 3) Dedication to Artemis made by Hekataie (256 $\mathrm{n}^{\circ}$ 8; 4th/3rd cent.). 4) Dedication to Hadrian Olympios and Sabina (256-258 $\mathrm{n}^{\circ}$ 9). 5) A boundary marker of the sanctuary of Zeus Ktesios belonging to the clan (patra) of the Menoitiadai (258-261 n ${ }^{\circ} 10$; ca. 400-350)

61) C. GRENET, "Manumission in Hellenistic Boeotia: New Considerations on the Chronology of the Inscriptions", in The Epigraphy of Boeotia, p. 395-442 [BE 2015, 267]: After reviewing the chronology of the Boiotian manumission records, G. argues that the vast majority belongs to the 2nd cent.; there are a few records from the late 3rd cent. from Thespiai, and in Chaironeia the records continue into the early 1st cent. In Boiotia, manumissions took the form of the consecreation of the slave to a god (Sarapis and Isis, Artemis Eileithyia, Asklepios, Apollo, Meter Theon, Dionysos, Zeus Basileus, Trophonios, Herakles Charops; for references, see p. 426-430).

62) M. GRÜNBART, "Magisches aus Münster. Ein Siegel Salomons im Archäologischen Museum der Westfällischen Wilhelm-Universität", Boreas 35 (2012), p. 169-172 [BE 2015, 81; SEG LXII 1824]: Ed. pr. of an amulet of unknown provenance (4th cent. CE) with the

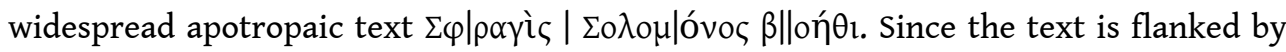
crosses, the amulet was used by a Christian.

63) J. HANICK, "The Great Dionysia and the End of the Peloponnesian War", ClAnt 33 (2014), p. 319-346: The epigraphic evidence suggests that the Great Dionysia were celebrated in $404 \mathrm{BCE}$, although in a reduced form, due to Athens' grim circumstances at the end of the Peloponnesian War. The first regular celebration after the war probably took place in $402 / 1$. 
64) R. HARAHSHAH, J. SEIGNE, “Jarash, Spring 2013”, ADAJ 57 (2013), p. 503-517 [SEG LXIII 1597]: Ed. pr. of a dedicatory inscription from Gerasa (Imperial period). A man

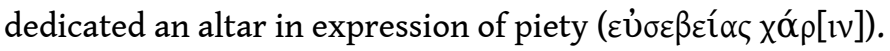

65) A. HERMARY, “Une petite énigme délienne : les 'curieuses offrandes' des hiéronautes de Tyr", RA (2014), p. 271-284 [BE 2014, 64]: A Greek-Phoenician inscription from Delos, considered lost but in fact in the Epigraphical Museum in Athens, reports on a

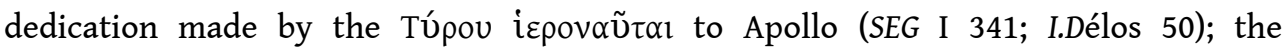
hieronautai probably were participants in sacred missions. The dedicated objects were

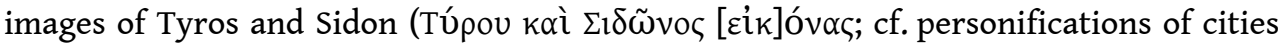
on coins of Euagoras II of Salamis and Cypriot statues of this period).

66) M. HORSTER, "Priene: Civic Priests and Koinon-Priesthoods in the Hellenistic Period", in Cities and Priests, p. 177-208: H. gives an overview of the various priesthoods attested in Priene (priestesses of Athena Polias, Demeter and Kore, Meter Phrygie; priests of Dionysos Phleios, Zeus Basileus and the Kouretes, Zeus and Poseidon, King Nikomedes II, and the Egyptian cults). She discusses the selection method and duration of priesthoods (priesthoods sold for life, annual elections), the priesthood of Poseidon Helikonios in the Panionion which was held by a Prienian, honorary decrees for priests, and diagraphai for the duties of priests.

67) B. IPLIKÇıĞLU, "Epigraphic-Historical Geography Surveys in Eastern and Northeastern Lycia - Southwest Pisidia in 2012", Anatolian Mediterranean Archaeological News 11 (2013), p. 215-217 [SEG LXIII 1298, 1303, 1374]: I. briefly presents new epigraphic finds from Arykanda, Elmall, and Rhodiapolis (p. 215f., Imperial period, if not otherwise stated). Arykanda: Two dedications to Artemis Kombike, and to the Dioskouroi and Helena. Elmall: A dedication to Kakasbos by a slave. Rhodiapolis: Hellenistic texts: Dedications to 'A $\rho \tau \varepsilon \mu \iota \varsigma, \Lambda \alpha \delta \beta \alpha v \eta$ and Athena; an honorific inscription refers to the victories of a boxer in the contests organized by the Lykian Koinon in

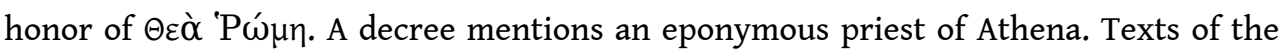
Imperial period: Dedications to Athena Polias, Eleuthera, and Poseidon.

68) S. ISAGER, P. PEDERSEN, "Dining Rooms in the Sanctuary: Old and New Epigraphic

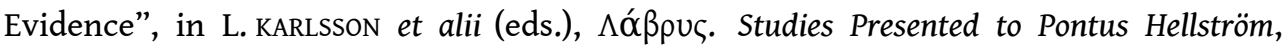
Uppsala, 2014, p. 507-523 [BE 2015, 25, 638]: The existence of dinning rooms (andrones) in Labraunda, as part of the building program of the Hekatomnids, is well known, but similar constructions are hitherto unknown in Halikarnassos. I.-P. associate with such dinning rooms two already known inscriptions: a dedication by Melas of an $\dot{\alpha} v \delta \rho \omega ́ v$ to Zeus Akraios (ca. 400-350; cf. a similar dedication to Artemis Astias in Iasos: EBGR 2009,

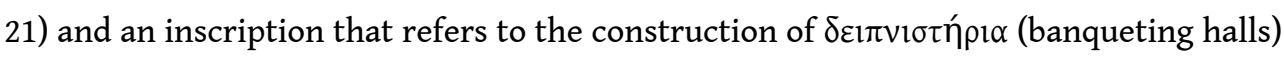
dedicated to Claudius and Artemis Delie.

69) C.P. JONES, "Two Late Antique Inscriptions from Aphrodisias", EA 46 (2013) 169-175: [SEG LXIII 859]: J. presents an improved edition of a Late Antique grave epigram for a young woman from Aphrodisias (ALA 154, 4th cent. CE; p. 172-175). The vocabulary and imagery of the text, which alludes to a blessed afterlife and the idea that the soul has

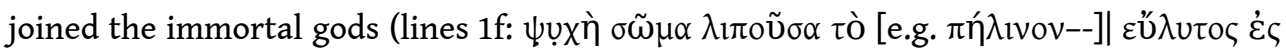

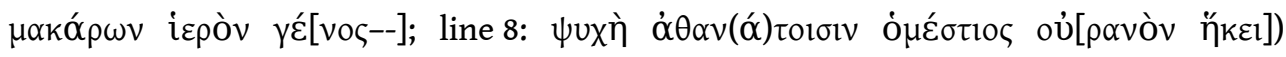
probably reflect Neoplatonic influences.

70) C.P. JONES, "Epigraphica X-XII", ZPE 188 (2014), p. 28-34 [BE 2014, 467]: J. restores the epithet Lochia in a dedicatory inscription from Laodikeia [see infra $\mathrm{n}^{\text {os }} 88$ and 122]. The 
dedicant, the governor of Phrygia and Caria Dyscolius, may have made this dedication to Artemis Lochia after his wife had been successfully delivered of a child during his term as governor.

71) C.P. JONES, “A 'New Hero' at Attea (Mysia)”, ZPE 192 (2014), p. 156-158 [BE 2015, 606; SEG LXIII 1017]: J. republishes a dedicatory inscription from Attea in Mysia for the "new hero' Menandros, son of Apollonios (cf. EBGR 2013, 114). The Greek and Roman citizens of Attea 'set an altar with base by means of ceremonies (consequent on) the dreams and

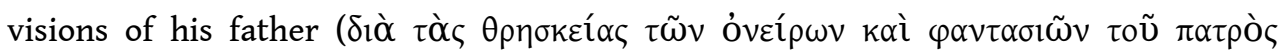

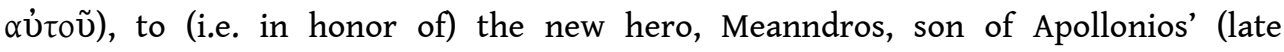
Hellenistic/early Imperial period). J. points out that vÉoৎ ň $\rho \omega \varsigma$ does not mean that Menandros had recently died; it is a reference to the young man's heroization. For $\theta p \eta \sigma \kappa \varepsilon i \widetilde{\alpha} \mathrm{l}$ he adduces a dedication from Sparta (SEG XI 683). The establishment of a cult of a dead child by a grieving father (an Alexandrian Jew) is mentioned in the Wisdom of Solomon (Sap. Sol. 14.15-16). Epikrates, the author of the famous 'testament of Epikrates' (P. HeRrmanN, K.Z. PolatKan, Das Testament des Epikrates, Vienna, 1969), received instructions to establish the cult of his son by his son who appeared in his dreams and visions. [This evidence, and that collected by C.P. JONES, New Heroes in Antiquity, Cambridge MA, 2010, confirms my suggestion that an inscription in Apollonia (I.Apollonia 238 = SEG XLVII 854; cf. EBGR 1997, 54) concerns the heroization of a

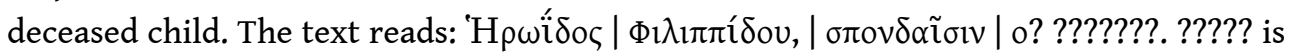
not the name of the deceased, but the designation of her status, followed by a ritual instruction: ?Of the heroine, the daughter of Philippides; honor her with libations [for

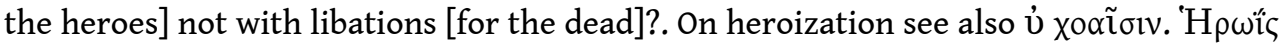
is not the name of the deceased, but the designation of her status, followed by a ritual instruction: 'Of the heroine, the daughter of Philippides; honor her with libations [for the heroes] not with libations [for the dead]'. On heroization see also infra $\mathrm{n}^{\circ}$ 93].

72) D.R. JoRdan, G. Rocca, L. threatte, "Una nuova defixio dalla Sicilia (Schøyen Collection MS 1700)”, ZPE 188 (2014), p. 231-236: Ed. pr. of a judicial defixio from Sicily (5th cent.), now in the Schøyen Collection. The text is addressed against the five adversaries of the defigens in court and wishes them to plead fruitlessly ( $\dot{\alpha} \tau \varepsilon \dot{\lambda} \varepsilon \sigma \tau$ '

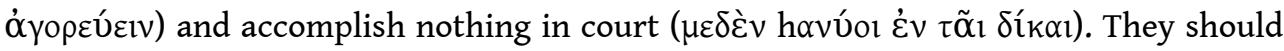
have the same fate as a certain oltis ('as Oltis going to/being at telos was destroyed, as

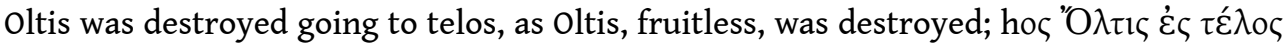

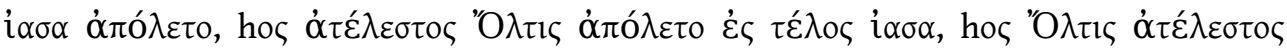
$\dot{\alpha} \pi \lambda_{\lambda \varepsilon \tau o)}$. This reference to Oltis is a local historiola, either referring to a woman with the name Oltis or to the destruction of the city of Olta (Pliny, NH II, 240) [in view of $\dot{\alpha} \tau \varepsilon ́ \lambda \varepsilon \sigma \tau o \zeta$ it seems more probable that Oltis was the unmarried and childless woman in whose grave the defixio was placed].

73) K. KALligA, "Die Keramik aus den Sondagen auf der Akropolis", in A. KONECNY, V. ARAVANTINOS, R. MARCHESE (eds.), Plataiai: Archäologie und Geschichte einer boiotischen Polis, Vienna, 2013, p. 241-328 [SEG LXIII 352]: Ed. pr. of a graffito on an Archaic kantharos, found in a deposit on the acropolis of Plataiai (ca. 550; p. 256). The vase is designated as

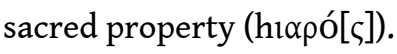

74) C. KAnellopoulos, E. zavvou, "The Agora of Gytheum", ABSA 109 (2014), p. 357-378 [BE 2015, 30]: Ed. pr. of an inscriprion from Gytheion that mentions the dedication to the Emperors (Theoi Sebastoi) and the city of an $\dot{\varepsilon} \xi \xi \dot{\varepsilon} \delta \rho \alpha$ (2nd cent. CE, p. 358). This 
monument, located in a colonnaded compound in the Agora of Gytheion may have been connected with the imperial cult.

75) P. KEen, G. PETZL, “Two 'Migrating Stones' with Three Inscriptions”, ZPE 191 (2014), p. 189-192 [BE 2015, 624]: Ed. pr. of an epitaph from Sardis (2nd/3rd cent.), now at the Brauer Museum of Art in Valparaiso, Indiana. The epitaph contains a funerary

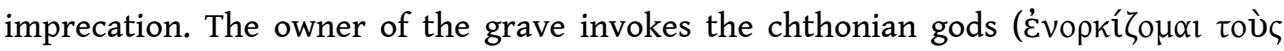

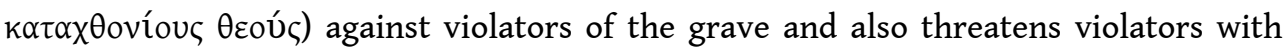
prosecution as tombrobbers.

76) A. KONECNY, "Der Kultbezirk am Theater - das Dionyseion von Plataiai?", in A. KONECNY, V. ARAVANTINOS, R. MARCESE (eds.), Plataiai: Archäologie und Geschichte einer boiotischen Polis, Vienna, 2013, p. 146-148 [SEG LXIII 350-351]: Ed. pr. of two boundary markers of a sanctuary (ö $\rho \varsigma \varsigma$ i $\varepsilon \rho o ́ \varsigma)$ near the theater of Plataiai, probably a sanctuary of Dionysos (p.148) [N. Papazarkadas in SEG LXIII 350, suggests dating it to the Hellenistic period].

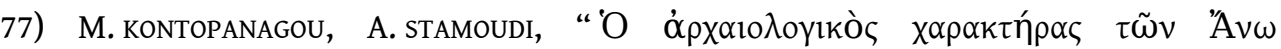

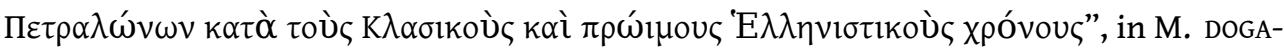

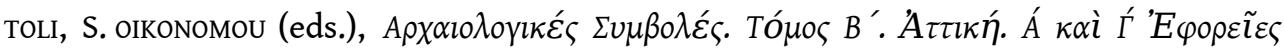

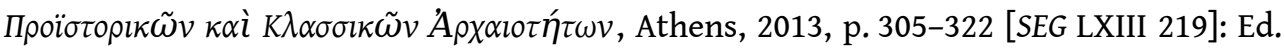
pr. of a Hellenistic vase with a graffito (p. 317); the vase was dedicated to Ariste Kalliste

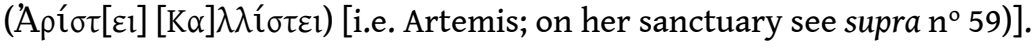

78) S. KouRsoumis, "Revisiting Mount Taygetos: The Sanctuary of Artemis Limnatis", ABSA 109 (2014), p. 191-222: K. collects and discusses the evidence for the sanctuary of Artemis Limnatis at Volimnos at the border of Messenia and Lakonia. This evidence includes several inscribed objects, mostly dedications by women, that mention the

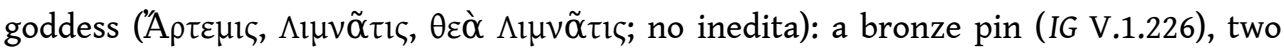
bronze mirrors (SEG XXIX 395 and P. OBERLÄNDER, Griechische Hanspiegel, Hamburg, 1967, 44 no. 52), and two cymbals or phialae (IG V.1.225; SEG XXXIV 306). Several stone inscriptions of the Imperial period mention the priests of Artemis and the $\dot{\alpha} \gamma \omega v o \theta \varepsilon \dot{\varepsilon} \tau \alpha$

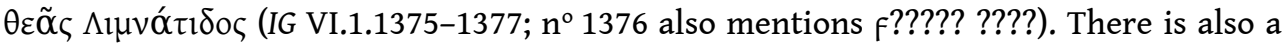

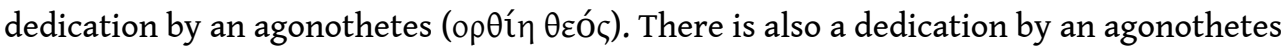
(SEG XXXIX 388) and fragments of an inscribed epistyle with part of the name of a Roman emperor (IG V.1.1373-1374a). The goddess was worshipped continuously from the Geometric period to the 3rd cent. CE.

204 79) E. Laffi, N. Buora, A. MASTRocinque, "A New Osirilamp from Antioch in the Hatay Archaeological Museum”, GRBS 52 (2012), p. 421-439: Ed. pr. of a mummiform lamp from Antioch ( $2 \mathrm{nd} / 3 \mathrm{rd}$ cent.). It represents Osiris wrapped in a bandage; a snake winds around him. The lamp is inscribed with magical spells known from Suppl. Mag. I 42 lines 40-42 and Greek Magical Amulets: The Inscribed Gold, Silver, Copper, and Bronze Lamellae. Part I. Published Texts of Known Provenance, Opladen, 1994, no. 4: $\Sigma \varepsilon \sigma \varepsilon[v \gamma] \varepsilon v$

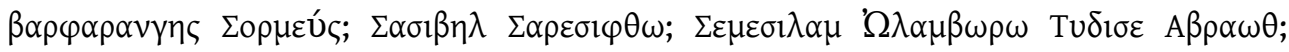

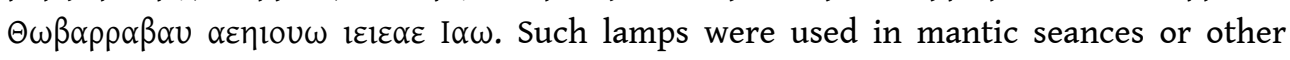
rituals.

80) A. ŁAJTAR, "Epigraphic Notes and Records", JJP 37 (2007) [2008], p. 153-163: Ed. pr. of a fragment joining a proskynema from Deir el-Bahari (I.Deir el-Bahari 247, Thebes, Imperial period). The text is engraved on a lotus capital probably from the columns of the Ptolemaic portico. 
81) A. ŁAJTAR, "A Newly Discovered Inscription at Novae (Moesia Inferior) Associated with pastus militum", Tyche 28 (2013), p. 97-111: Ed. pr. of an inscribed statue base from the fort of Legio I Italica in Novae (ca.350-400). Two primipilarii, responsible for securing the transport of provisions to the army in the limes, dedicated a statue of an

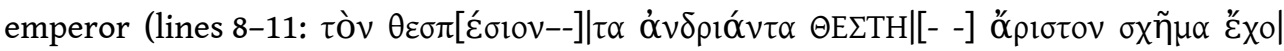
$[\nu \tau \alpha \sigma \kappa \varepsilon \cup \tilde{\eta} \varsigma$

$\sigma \tau] \rho \alpha \tau \imath(\omega \tau \imath \kappa) \tilde{\eta} \varsigma \kappa \alpha \grave{~} \pi \alpha v o \pi \lambda_{1} \mid[\tau \iota \kappa \tilde{\eta} \varsigma$ ?]). The two men made their dedication after a successful mission under difficult circumstances; they thank a god who is designated as

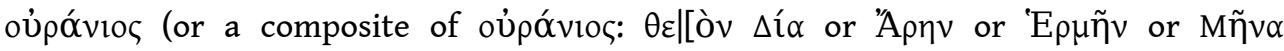

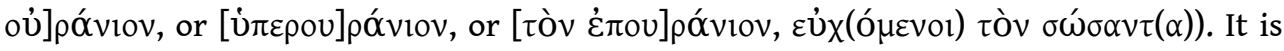
nor clear if the recipient of the dedication was a pagan or the Christian god. $\mathrm{t}$. also mentions an unpublished statue base, found in 2013 in the legionary fort. It is inscribed with an epigram referring to the dedication of the statue of $\Phi$ оĩ $\beta$ o by a primipilarius (p. 111).

82) V. LAMBRINoudakIS, "Das archäologische Projekt Palaiomanina", in Forschungen in Akarnanien, p. 127-136: A rock-cut inscription naming Zeus ( $\Delta$ ló $)$ was found inside the south wall of the lower acropolis of Palaiomanina in Akarnania (ancient Metropolis?), near the gate (early 4th cent.). L. suggests that the gate was placed under the protection of Zeus and provides parallels for gates and towers placed under the patronage of deities [see also IG XII.4.1189-1193]. It is possible that a sanctuary of Zeus existed in this area before the construction of the wall. [Since the inscription is inscribed on a rock, not on the wall, it is possible that it is the boundary marker of a sanctuary].

83) N. LANÉRÈs, "La dédicace du 'trône' d'Aléa SEG 40, 400, nouvelle lecture”, REG 125 (2012), p. 715-725 [SEG LXII 212]: L. discusses the dedicatory epigram inscribed on a throne dedicated to Alea by a member of the gerousia (SEG XLVI 400, ca. 400-375). For

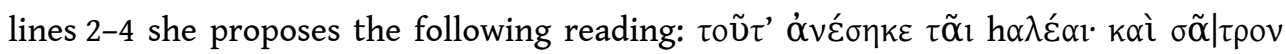

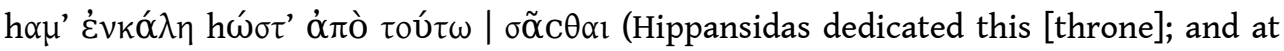
the same time he invited the public to watch the spectacle from [this throne]). The

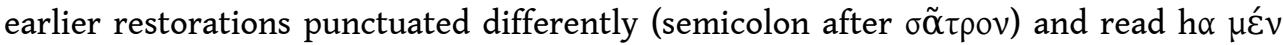
$\kappa \alpha \lambda \tilde{\eta}$ [see EBGR 2003, 25; A. STRIANO, "À propos d'une nouvelle inscription laconienne", in I. HAJNAL (ed.), Die altgriechischen Dialekte. Wesen und Werden, Innsbruck, 2007, p. 449462 , read $\kappa \alpha \lambda \eta$ ']. L. provides parallels for the use of $\sigma \tilde{\alpha} \tau \rho o v$ (i.e. $\theta \varepsilon \dot{\varepsilon} \tau \tau \rho v$ ) in the meaning 'assembly of spectators, audience' and the unaugmented imperfect ह่vкó $\lambda \eta$ [see also infra $\left.\mathrm{n}^{\circ} 138\right]$.

84) W. MACK, "Consulting the Oracle at Dodona about a Female Proxenos? Lhôte no. 15

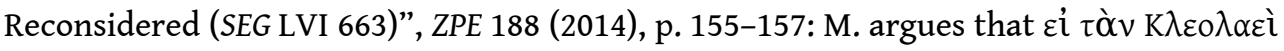
$\pi \rho \circ \xi \varepsilon v \varepsilon[i ́ \alpha v \delta o ́ \mu \varepsilon v--]$ in an oracular tablet from Dodona (Lhôte, Lamelles oraculaires $\mathrm{n}^{\circ}$ 15) is not an inquiry about granting proxenia to a woman (K???????) but an inquiry about rescinding ([??????? or ????????]) the proxenia of a man; ???????? is a hypercorrect dative of ??????? (???????? for ???????).

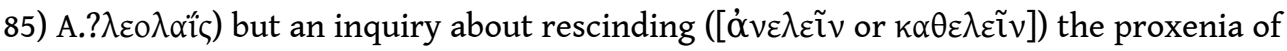

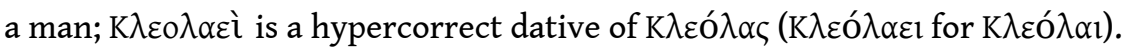

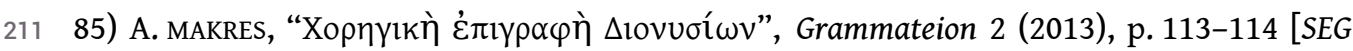
LXIII 162]: Ed. pr. of a dedication made by the choregos of the tribe Aigeis, after 
winning the competition of the men's dithyrambic chorus at the Dionysia (Athens, ca. 400-350).

86) H. MALAY, F. eRTUĞRUL, "A Dedication to the River-God Harpasos from Bargasa in Caria", EA 47 (2014), p. 13-15 [BE 2015, 628]: Ed. pr. of a dedicatory altar from Bargasa, near the river Harpasos. The relief shows a man with helmet, shield and sword fighting against a snake with many heads (hydra). He may be Bargasos, Herakles' son and founder of Bargasa. His fight against the hydra may symbolize a fight against the ravaging river, that turned the river into a beneficial deity. The dedication was made by Flavius Ouliades to Theos Harpasos after a dream ( $\kappa \alpha \tau^{\prime}$ óv $\left.\alpha \rho\right)$.

87) G. MANGANARo, "Tre note di storia e di epigrafia della Sicilia", Epigraphica 75 (2013), p. 9-32: M. returns to a dedication to Hera from Samos (late 6th cent.; IG XII.6.575). He rejects the view that the dedicated object was a shield (A line 7: [ $\dot{\alpha}] \sigma \pi \hat{\imath}\langle v\rangle$, for $\dot{\alpha} \sigma \pi \hat{i} \delta \alpha$;

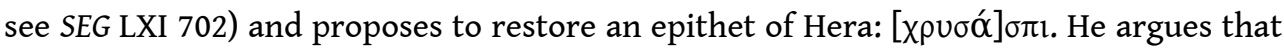
the dedicants were two Samian brothers, mercenaries or sailors, who served in a garrison at Endesa ('hanno presidiato Endesa') and made their dedication in fulfillment

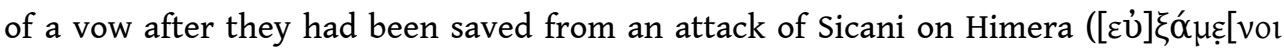

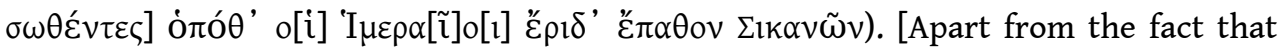
Hera is nowhere designated $\chi \rho \tilde{\sigma} \sigma \alpha \sigma ı \varsigma$, this restoration presupposes that in A line 4 the text started further to the left than all the other lines; the dr. of A line 5 in IG does not justify the restoration $\left.[\varepsilon \dot{U}] \xi \alpha_{\alpha}^{\mu} \mu\left[{ }^{2} \mathrm{vol}\right]\right]$.

214 88) G. MANGANARO, "Revisione di due iscrizioni greche", Epigraphica 75 (2013), p. 470-481 [BE 2014, 467]: M. proposes new restorations to a puzzling text from Morgantina, inscribed after firing on a clay tablet (SEG XLIX 1314; IGDS II 105; p. 470-478). The text contains a list of animals. What can be recognized with certainty are only deer

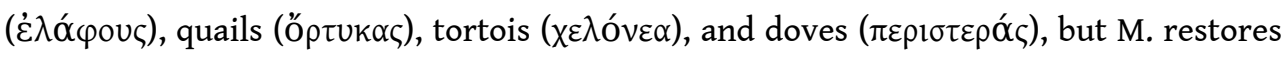
a long list of animals, including sheep, goats, oxen, and chicken. In his interpretation, this is an 'anomale lex sacra' (p. 476) listing animals that were to be raised in a temenos

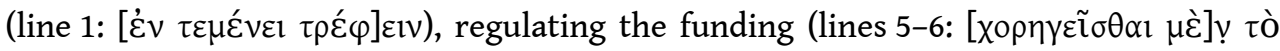
$\delta \alpha \pi \alpha \dot{\alpha}[v \eta \mu \alpha])$, and making provisions against harming the animals and sacrificing birds

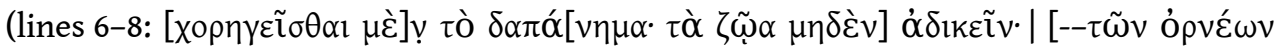

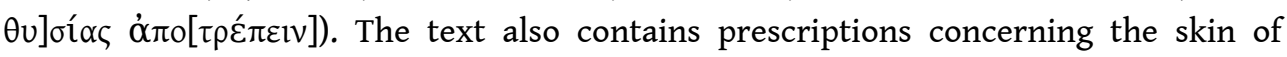
sheep and the burning of sacrificial animals (lines 8-9: ö́ ?? ??????-???] ???????????). [The text remains puzzling. The restorations are in part arbitrary, in part impossible. There can be no reference to funding ([??????????? ??]?? ?? ????[???]) without a reference to the source of the funding. The use of ????????? in prohibitions is unattested]. M. also republishes a dedication from

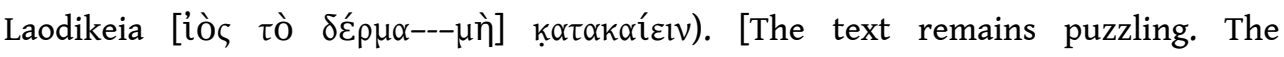
restorations are in part arbitrary, in part impossible. There can be no reference to

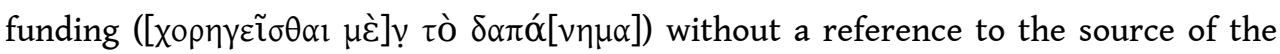

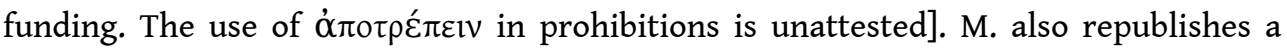
dedication from Laodikeia [infra $n^{\circ} 122$ ], where he suggests reading the epithet of Artemis as $[\Lambda]$ oxíac. The governor Dyskolios made this dedication for his wife or daughter. Dedications to Artenis Lochia by men are rare (BE 1970, 43). M. suggests dating this text either before $324 \mathrm{CE}$ or under Julian. [The same interpretation has been independently suggested by C.P. Jones; see supra $\left.\mathrm{n}^{\circ} 70\right]$. 
215 89) A. MANIERI, “I Soteria anfizionici a Delfi: concorso o spettacolo musicale?", ZPE 184 (2013), p. 139-146: M. studies the formulations used in the inscriptions concerning the amphiktyonic Soteria at Delphi (ca.278-mid-3rdcent.). The earlier texts use the

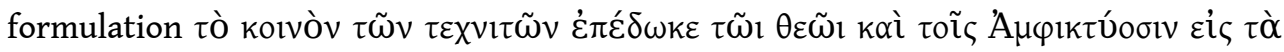

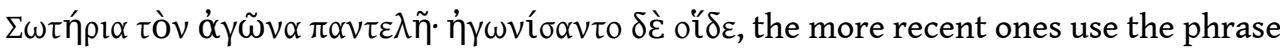

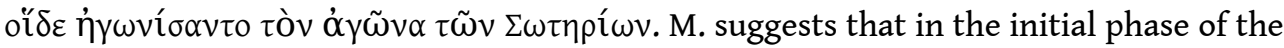
Soteria the Isthmian Koinon was responsible for the organization of the entire festival, and its members participated without an honorarium (cf. $\dot{\varepsilon} \pi \varepsilon \delta \omega \varepsilon$ ); in later years, artists that belonged to different koina participated in the festival. The participation of artists without an honorarium does not mean that there were no competitions in which the winners received prizes. The Delphic documents do not mention victors because they are not agonistic catalogues but documents that acknowledge the service of the participants.

90) E. MATRICON-THOMAS, “Adonis à Athènes : le culte en milieu chyprio-phénicien", Rivista di Studi Fenici 39 (2011), p. 67-79 [SEG LXIII 27]: M.-T. examines two Athenian inscriptions related to the cult of Adonis: three decrees of a cult association (thiasotai) which honored Stephanos for taking care of a procession in honor of Adonis, serving as hieropoios of the association, and taking care of the sacrifice for Aphrodite (IG $\mathrm{II}^{2} 1261$, late 4th cent.), and a fragmentary decree of the Salaminians of Cyprus referring to Aphrodite and the festival of the Adonia (IG II $^{2}$ 1290, ca. 250). She argues that the members of the association that honored Stephanos were Cypriots, probably

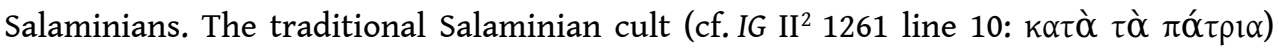
combined Eteocypriote and Phoenician elements and should be distinguished from the Athenian cult of Adonis. In Cyprus, Adonis was worshipped as a god, often in association with Aphrodite.

91) L. MEIER, "Priests and Funding of Public Buildings on Cos and Elsewhere", in Cities and Priests, p. 41-49: M. studies the information provided by the Koan regulations concerning the sale of priesthoods (IG XII.4.296b, 302, 304b, 311, 315, 319, 325/326) for the financial contributions of priests to the construction and upkeep of buildings. $\mathrm{He}$ also adduces evidence for similar contributions by priests in other cities (IG II ${ }^{2} 1046$; V. 1.1144-1146; I.Oropos 290, 294; Tit.Cam. 52; I.Ephesos 618; I.Prusias ad Hypium 20; I.Sestos 1; Syll. ${ }^{3}$ 1015; TAM II 550/551).

218 92) G. MEYER, "Non pas Athènes mais Épidaure. À propos d'une inscription publiée par Jacob Spon et du voyage en Grèce du numismate Jean Vaillant", REG 125 (2012), p. 289295 [SEG LXII 193]: M. discusses an inscription only known from early publications (most recent edition: F. LENORMANT, RhM 21 [1866], p. $387 \mathrm{n}^{\circ} 210$ ). The text is not an epitaph from Athens but a dedication to Apollo and Asklepios from Epidauros (2nd/ 1st cent.).

219 93) N. P. MILNER, “Athletics, Army Recruitment, and Heroization: L. Sep. Fl. Flavillianus of Oinoanda", AS 61 (2011), p. 151-167 [SEG LXI 1238]: Ed. pr. of an honorific inscription for a Roman knight from Oinoanda who inter alia had been responsible for the recruitment of local men for the Roman army. He is also known from other inscriptions as a successful wrestler and pankratiast (SEG XLIV 1169, 1194-1196 and IGR III.500 IV). After his death he should be included among the recipients of heroic cult by his tribe

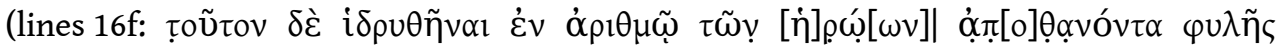

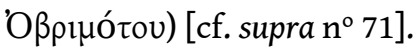


94) N.P. MILNER, "Some Funerary Reliefs and Inscriptions Attributed to Tlos, Lycia", EA 46 (2013), p. 81-90 [BE 2014, 450]: Ed. pr. of epitaphs with funerary imprecations from a private collection, allegedly from Tlos. An epitaph(1) has the curse formula

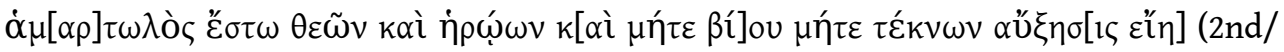
1st cent.) [if the date is correct, this is one of the earliest funerary imprecations]. A

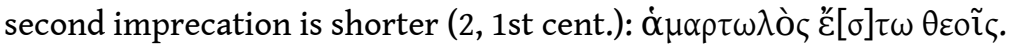

95) J. MYLONOPoulos, "Commemorating Pious Service: Images in Honour of Male and Female Priestly Officers in Asia Minor and the Eastern Aegean in Hellenistic and Roman Times", in Cities and Priests, p. 121-153: M. collects epigraphic evidence for honorific statues for priests/priestesses and other cult officials in Messene, Kos, Priene, Aphrodisias, and Stratonikeia. The statues were usually dedicated by civic authorities, but also by the priests and priestesses themselves and family members. The statues of priestesses were usually placed near or in a sanctuary (rarely inside the temple); statues of priests were often set up in public spaces, such as agoras. Generally, the honors for cult personnel were far more modest than those for benefactors.

96) F.S. NAIDEN, “So-called 'Asylum' for Suppliants”, ZPE 188 (2014), p. 136-137: Stressing the difference between the right of asylia granted to shrines and cities and supplication at a public altar, N. argues that the reconciliation agreement of Dikaia (SEG LVII 576, ca. 363 BCE) that allows the removal of suppliants from altars if they had violated the oath does not concern the right of asylum or asylia (contra: EBGR 2008, 156). In N.'s view 'the purpose of the oath is not to create a mechanism, but to ensure that citizens use the power of removal against enemies of the community'. He provides examples of cases in which suppliants were rejected or removed from altars because they were a threat to public order. [N. is wrong in assuming that the citizens of Dikaia automatically had the 'power of removal'. The removal of suppliants from altars or sanctuaries did occur, but it was always regarded as a violation of custom. Although modern historians should distinguish between the $\dot{\alpha} \sigma u \lambda i ́ \alpha$ of cities/sanctuaries and the individual supplication, the right of a suppliant to be protected from seizure is part of the general Greek concept of $\dot{\alpha} \sigma u \lambda i ́ \alpha$, that is, the protection of individuals who are in a sacred space from seizure. As a matter of fact, the asylia documents from Nysa (early

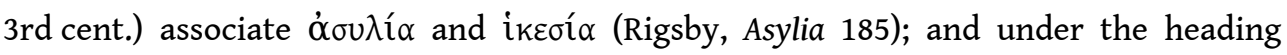

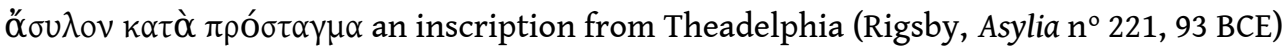
deals with suppliants (lines 12/13: ‘??? ??? ????? ????????????????????)].

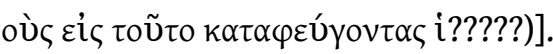

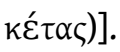

97) P. NIGDELIS, "Katalog", in T. STEFANIDOU-TIVERIOU, Die lokalen Sarkophage aus Thessaloniki, Thessaloniki, 2014, p. 157-289: N. presents critical editions of the inscriptions on sarcophagi that were produced in Thessalonike (no new texts). We note an epitaph in which the deceased is called neos heros ( $1=I G$ X.2.1.540, ca. 140) [on neoi

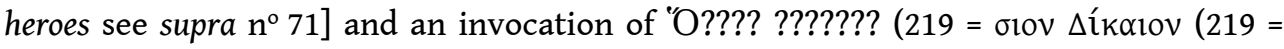

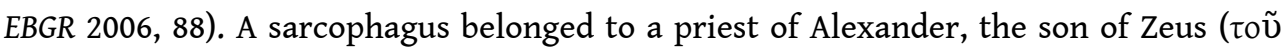

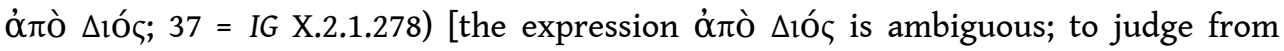

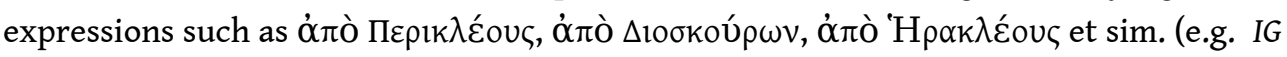
$\mathrm{II}^{2}$ 3546; IG V.1.471, 559), it may mean 'the descendant of Zeus']. Two epigrams refer to the afterlife, to the place of the Blessed in the underworld (68 = IG X.2.1.628: ["̌́ $\sigma \tau l ~ \gamma \grave{\alpha} \rho$ ] 


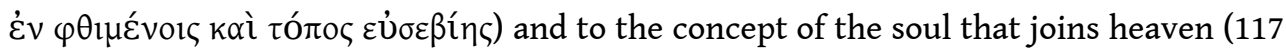

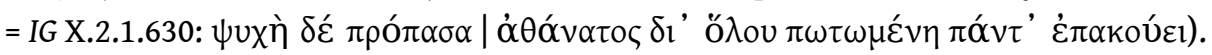

98) H.S. özTÜRK, "New Inscriptions from Nicaea IV: Iznik Archaeological Museum (Bursa)", Cedrus 1 (2013), p. 293-298 [BE 2014, 477; SEG LXIII 1142]: Ed. pr. of two dedications from Nikaia (1st/2nd cent). A woman made a dedication to Thea Artemis in accordance with a dream ( $\kappa \alpha \tau \grave{\alpha}$ ǒv $\alpha$ ) for the well-being of her son and her household (2). The second dedication is addressed to Zeus Soter (3).

99) I. PAFFoRD, "Priestly Portion vs. Cult Fees. The Finances of Greek Sanctuaries", in Cities and Priests, p. 49-64: P. exploits the epigraphic evidence, especially cult regulations, dedications, and inscriptions on offering boxes (thesauroi), for a study of 'sacred accounting', i.e. the way priests dealt with the revenues of sanctuaries (coins given by worshippers as offerings, priestly revenues; cf. IG I ${ }^{3}$ 6; IG II ${ }^{2}$ 1356; IG XII.4.302; IG XII.7.241; I.Oropos 290, 324; LSCG Suppl. 72; Thasos); SEG XLI 182; IG XI.4.1247; I.Délos 1898).

100) M. PAGANINI, “A Ptolemaic Inscription Rediscovered”, ZPE 189 (2014), p. 127-132: A dedication made by a gymnasiarchos to Hermes and Herakles for the well-being of Ptolemy V and Kleopatra I (ca. 186-180; M.L. STRACK, "Inschriften aus ptolemäischer Zeit II', APF 2 [1903], p. $548 \mathrm{n}^{\circ}$ 26) is kept in the Britsh Museum. An examination of the stone shows that its provenance is Terenouthis.

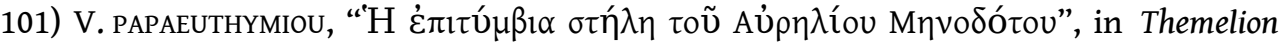
Themelis, p. 87-105 [SEG LXIII 187]: Ed. pr. of a funerary epigram for a man who died at the age of 17 (Athens, 3rd cent. CE). His death is attributed to the envy of the Moirai

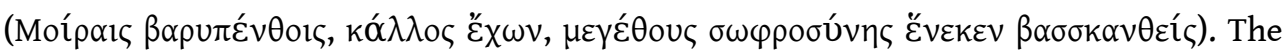

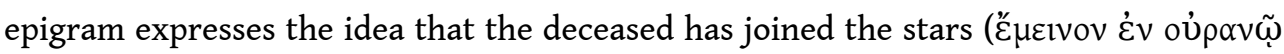

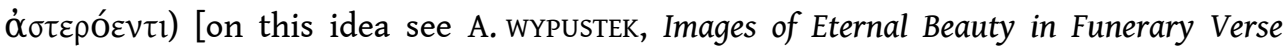
Inscriptions of the Hellenistic and Greco-Roman Periods, Leiden, 2012, p. 48-57].

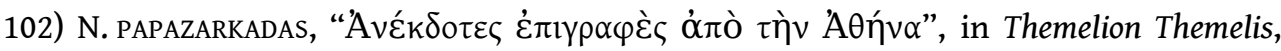
p. 233-245 [BE 2014, 152; SEG LXIII 53]: Ed. pr. of a boundary stone of a sanctuary

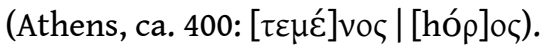

231 103) N. PAPAZARKADAS, "Two New Epigrams from Thebes", in The Epigraphy of Boeotia, p. 223-251 [BE 2015, 306]: Ed. pr. of an inscribed column drum from Thebes (p. 233-247). The column was inscribed twice with the same epigram. The earlier version (late 6th/ early 5th cent.) uses the Boiotian, the later (4th cent.) the Ionic alphabet. The epigram,

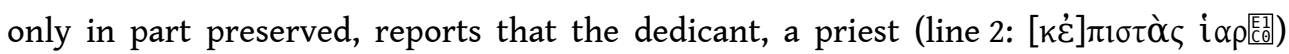
dedicated to Apollo, certainly Apollo Ismenios, the shield that Kroisos had dedicated to

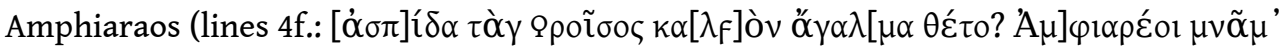
$\dot{\alpha} \rho \varepsilon \tau[\tilde{\alpha} \varsigma \tau \varepsilon \pi \alpha \dot{\alpha} \theta \alpha \zeta \tau \varepsilon])$. The historical context of the dedication of weapons by Kroisos the consultation and testing of oracles in Greece - is narrated by Herodotus (1.52), who claims that he saw these dedications in the sanctuary of Apollo Ismenios. The epigram reports that the priest rediscovered the shield that had been stolen (line 6: $\grave{\alpha} \dot{\varepsilon} \kappa \lambda \dot{\varepsilon} \varphi \theta \varepsilon$ )

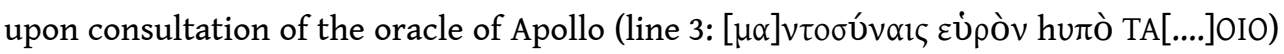
[on the discovery of an object and its dedication, cf. SEG XXVI 1288, now republished in

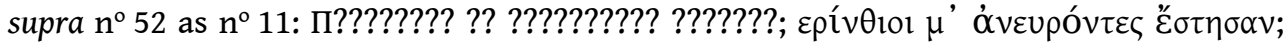

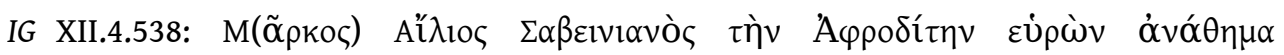

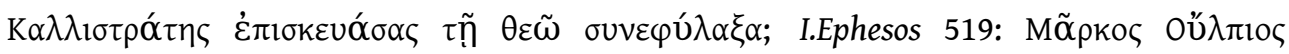

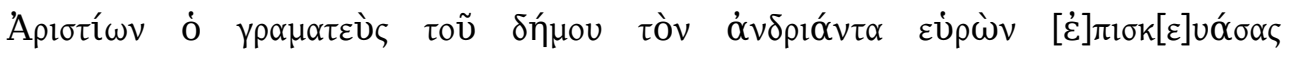




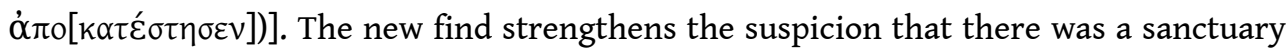
of Amphiaraos close to Thebes, in addition to the one at Oropos. A difference between

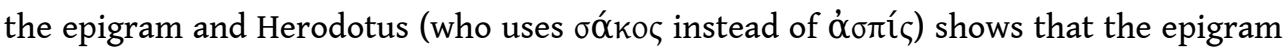
is not the text seen by the historian. [For a different (not convincing) interpretation (the original dedicant was not King Kroisos but a young Athenian killed in war), see P. THONEMANN, "Croesus and the Oracles", JHS 136 (2016), p. 152-167, to be presented in EBGR 2016].

104) S. PAUL, Cultes et sanctuaires de l'île de Cos, Liège, 2013 [BE 2014, 370; SEG LXIII 658]: This exhaustive, systematic study of the organization and practice of religious worship in the city and demes of Kos is primarily based on the epigraphic evidence. The individual chapters are dedicated to the following subjects: the divinities worshipped in Kos (Adrasteia; Aphrodite Pandemos, Pontia; Apollo Dalios, Karneios, Pythios; Artemis Toxitis, Lochia; Athena; Charites; Demeter; Demos; Dionysos Skyllitas, Thyllophoros; Dodekatheon; Hera; Herakles Kallinikos, Diomedonteios; Hermes Enagonios; Homonoia; Nemesis; Nike; Nymphs; Poseidon; Zeus Alseios, Machaneus, Polieus, Soter; p. 29-165); the Asklepieion and the cult of Asklepios (167-187); the cults of the demes (Halasarna: Aphrodite, Apollo, Herakles; p. 189-220; Isthmos: Aphrodite, Apollo Oulios, Asklepios, Hestia Phamia, Hygieia, Homonoia; p. 221-235; other demes; p. 237-257); the associations of divinities and their various properties ('configurations panthéoniques'; p. 261-326); sacrificial rituals and sacrificial calendars (p. 327-365). Naturally, the numerous cult regulations of Kos and the diagraphai for the sale of priesthoods (see EBGR 2011, 21) are adduced and discussed in great detail.

105) S. PAUL "Roles of Civic Priests in Hellenistic Cos", in Cities and Priests, p. 247-278 [BE 2014, 371]: Making use of the extensive epigraphic evidence from Hellenistic Kos, P. discusses various aspects of civic priestshoods: the appointment of priests, the attribution of priesthoods to civic subdivisions and $\gamma \varepsilon$ v $\eta$, and the sale of priesthoods (cf. IG XII.4.278, 310, 332, 348, 350, 721; p. 248-254), the consecration of the priest ( $\varepsilon \varepsilon \lambda \varepsilon \tau \alpha$; see esp. IG XII.4.332; p. 254f.), purity regulations for priests (IG XII.4.330, 332,

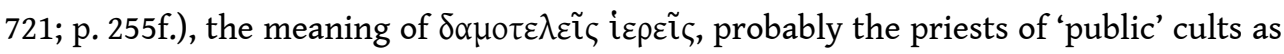

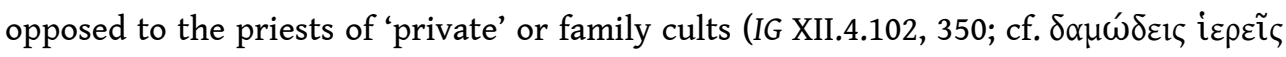
in IG XII.4.320; p. 256-260), and the cultic duties of priests (clothing regulations, sacrifices, perquisites; cf. IG XII.4.274, 278, 298, 315, 318, 339; p. 261-273).

106) A. PEtrovic, I. Petrovic, "On Ritual Pollution by Seeing: I.Lindos II 487.1-3 and Hdt. 2.37.5", Gephyra 11 (2014), p. 29-35: A cult regulation concerning purity from Lindos (I.Lindos 487) prescribes that those who enter the sacred space passing the basins and the temple gates should abstain from looking at [breast-fed?] children (

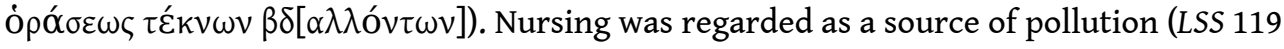
line 6; LSCG 68), but a visual taboo is unique in Greek religion. It may have aimed at protecting nursing mothers or children from the malevolent gaze. Considering the connections of the sanctuary of Athena Lindia with Egypt, the authors argue that refraining from even looking at a source of pollution may reflect Egyptian influence (cf. Herodotus 2.37.5: The Egyptian priests cannot endure even to see beans).

107) O. PILz, "The Profits of Self-representation: Statues of Female Cult Personnel in the Late Classical and Hellenistic Periods', in Cities and Priests, p. 155-175: P. gives an overview of statues of female cult personnel (ca. 4 th-1st cent.), both erected by priestesses and by family members, and discusses the 'symbolic capital' that privately dedicated statues produced. 


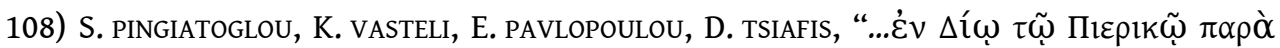

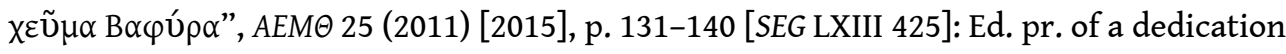

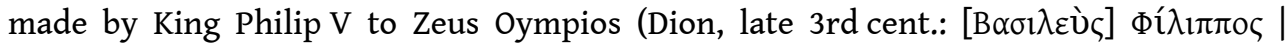

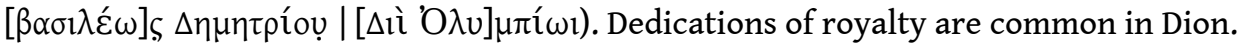

109) V. PIRENNE-Delforge, G. PIRONTI, "Héra et Zeus à Lesbos: entre poésie lyrique et décret civique", ZPE 191 (2014), p. 27-31: A shared sanctuary of the cities of Lesbos was dedicated to Zeus, Hera, and Dionysos (cf. Sappho fr. 17 ed. Voigt; Alkaios fr. 129 ed. Voigt). The cult of Hera Basileia is now also attested in a new poem of Sappho ('The Brothers Poem'; D. OBBINK, “Two New Poems of Sappho”, ZPE 189 [2014], p. 32-49) which

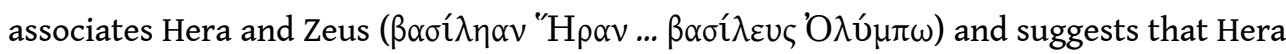
was a patron of both young women and men. For the importance of Hera on Lesbos the authors adduce the decree of Mytilene concerning a prayer for the success of a reconciliation agreement (SEG XXXVI 750, $332 \mathrm{BCE}$ ). The epithets of Zeus ( $\tau \tilde{\omega}_{\imath} \Delta \mathrm{il} \tau \tilde{\omega} \iota$

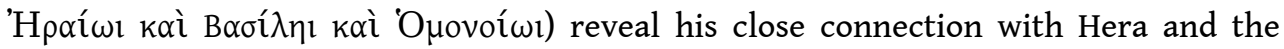
significance of Hera's cult.

110) I. PISO, "Studia Porolissensia (IV)", Revista Bistriţei 27 (2013), p. 39-51: Ed. pr. of a dedication to a god whose name is not preserved on the stone (Potaissa, Imperial period; $\left.39 f . n^{\circ} 1\right)$. The dedication was made in fulfillment of a vow $\varepsilon$ ?[???]. 111) R.?ủ[xńv].

111) R. PITT, "Just as It Has Been Written: Inscribing Building Contracts at Lebadeia", in The Epigraphy of Boeotia, p. 373-394: P. presents an overview of the building contracts for the construction of the temple of Zeus Basileus in Lebadeia (late 3rd-2nd cent.). He presents a new edition of a fragmentary contract, which describes the obligation of the constructors and the duties of the naopoioi (SEG XLIV 413, 220), and discusses two further contracts (IG VII 3073-3074).

241 112) S. PRIGNITZ, "Zur Identifizierung des Heiligtums von Kalapodi", ZPE 189 (2014), p. 133-146 [BE 2015, 363]: An examination of the inscriptions found at the sanctuary in Kalapodi and its vicinity, including two new honorific inscriptions for emperors set up by Abai, suggest that the city near Kalapodi should be identified as Abai. The sanctuary was the oracle of Apollo at Abai.

113) S. PRIGNITZ, Bauurkunden und Bauprogramm von Epidauros (400-350). Asklepiostempel Tholos - Kultbild - Brunnenhaus, Munich, 2014: P. presents a new, significantly improved edition of the four building accounts of Epidauros (IG IV $2.102,103,104+117+743+$ new fragments, and 112) that provide information on four major projects of the first half of the 4th cent: the building of the temple of Asklepios, the construction of the cult statue of Asklepios, the construction of the tholos, and the construction of the fountain. P. examines in detail the administrative, financial, and legal aspects of the acounts and the information that they provide for the workers, their contracts, and their payment, the accounting process, and the progress of the work. P. convincingly argues that the temple of Asklepios is earlier than generally thought, built between 400 and 390 BCE. The construction of the subterranean labyrinth of the Tholos started before $375 \mathrm{BCE}$, but the project was completed after $351 \mathrm{BCE}$. The cult image of Asklepios, a work of Thrasymedes, was finished in ca. $370 \mathrm{BCE}$.

114) F. QUEYReL, “Apollon et le Colosse des Naxiens", RA (2014), p. 245-258 [BE 2015, 71]:

W. returns to the famous Archaic inscription on the base of the colossal statue of Apollo

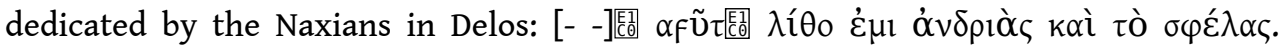


Reviewing the various restorations proposed for the text, he assumes that the dedication consisted of two lines, written in the boustrophedon style. Only the last words of the second line are preserved. The text is composed in iambic trimeter.

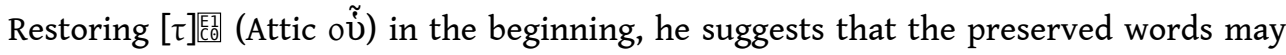
belong to a relative sentence: 'duquel même je suis en marbre, moi la statue, ainsi que la base' or 'duquel marbre précisement je suis, moi la statue, ainsi que la base'.

115) G. RENBERG, "Unexplored Aspects of the Lycian 'Twelve Gods Reliefs", EA 47 (2014), p. 107-132: Ca. 55 reliefs with a homogeneous iconography (representations of twelve gods and their hounds) are known from rural areas of Lykia, but they cannot be linked with a particular sanctuary. The inscriptions refer to the father of the Twelve Gods, Artemis Kynegetis, and Hermes. The most striking feature of these votives is that

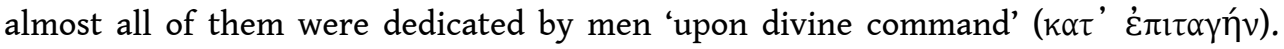
After giving an overview of the iconography, the inscriptions, and the findspots of these reliefs and comparing them with other dedicatory reliefs from Asia Minor, R. argues that these votive offerings represent a religious phenomenon of limited duration in Lykia and southern Pisidia (ca. $200 \mathrm{CE}$ ). Instructions given by an oracular sanctuary (or more than one oracle) may have prompted this phenomenon.

116) M. RICL, E. AKINCI ÖZTÜRK, “A New Benefactor from the Upper Maeander Valley”, EA 47 (2014), p. 16-20 [BE 2015, 655]: Ed. pr. of an honorific decree from the modern village of Akkent (ancient Atyochorion, 2nd cent. CE). The decree honors an anonymous man for his services to his fatherland and especially to the cult of Asklepios. He had funded the construction of a temple (or an altar) of Asklepios on a plot belonging to him,

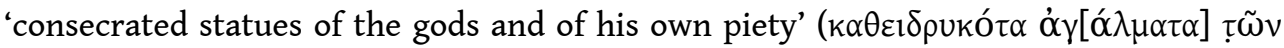

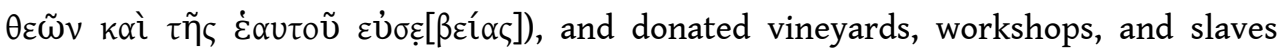
(restored), under the condition that the revenue from this donation be used for the cult and for the maintenance of the temple and the statues (

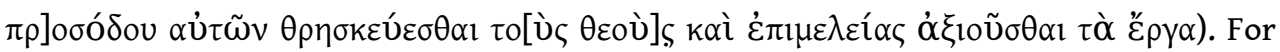
this reason, his anonymous community (probably Atyochorion) decided to give him the priesthood of Asklepios and the other gods who were worshipped together with Asklepios ( $\sigma \cup v \kappa \alpha \theta \varepsilon 1 \delta \rho u \mu \varepsilon ́ v o r ~ \theta \varepsilon o i)$ ); this probably was a hereditary priesthood. The

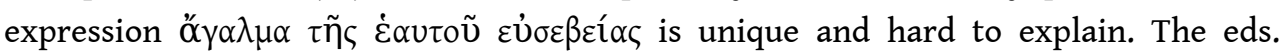

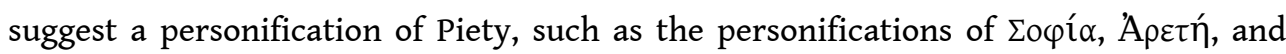

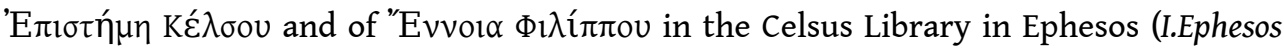
5108-5111) or statues of the Eusebeia of Claudius in Mylasa (I.Mylasa 33). [For a parallel see TAM III 302: ö́ $\alpha \lambda \mu \alpha$ ónovoí $\alpha$. Another, less likely, possibility is that the anonymous benefactor dedicated his own statue representing him in an act of piety

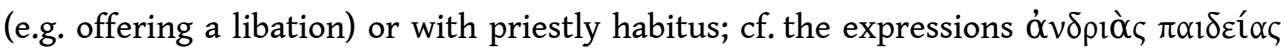

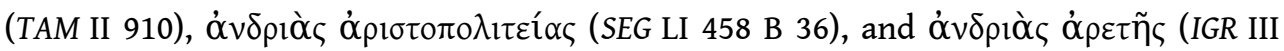
318) that do not refer to personifications of education, good conduct as a citizen, and virtue, but to images of men represented in a certain habitus. But since the text refers to ó $\gamma \alpha \lambda \mu \alpha$ and not $\dot{\alpha} v \delta \rho 1 \alpha ́ \varsigma$, a personification is far more probable].

246 117) T. RITTI, "Alcune figure femminili nelle iscrizioni di Hierapolis di Frigia", Mediterraneo Antico 16.1 (2013), p. 139-180 [BE 2015, 653; SEG LXIII 1227-1228, 1231, 1234-1237]: In a significant article on the part played by women in the public and religious life of Hierapolis, R. briefly presents the text of several inedita. An honorific inscription for a man, who possibly served as high-priest of the imperial cult (2nd cent. CE), mentions his heroization (ň $\rho \omega \alpha ;$ p. 157). An honorific inscription was set 
up for a priestess of the Gerousia (p. 174, ca. 200-250), who is known from another inscription as a donor of funds for the priestesses of the Gerousia (SEG XXXIII 1123). A small stele with a labrys in relief was dedicated by a woman in fulflment of a vow (દủxńv; p. 152; 2nd/3rd cent.). A priestess of Demeter dedicated a statue of an emperor (p. 147f., ca. 200-250). The most interesting text is the grave epigram for Pedia Tertia (p. 159f., ca. 100-125), who committed suicide upon her son's death and was buried in the same grave. Upon seeing her dead son she embraced him shedding tears ( $\pi \alpha \tilde{i} \delta \alpha$

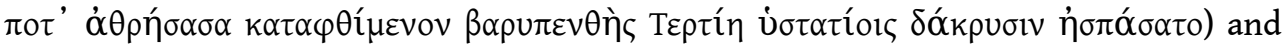
,she did not let him alone beyond the streams of Oblivion, but of her own free will she

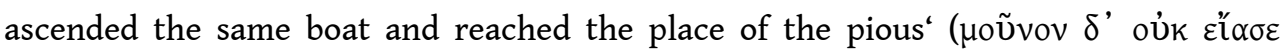

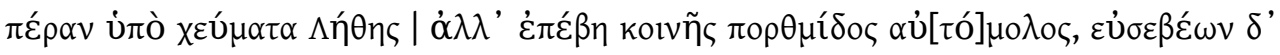

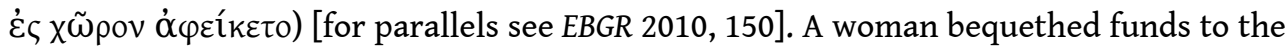
associations of the wool-washers and gardeners, in order that her grave is crowned

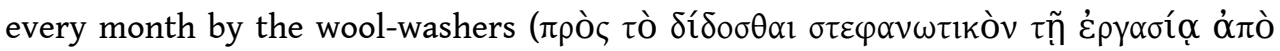

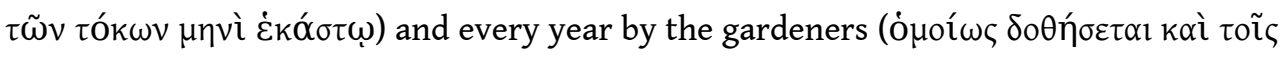

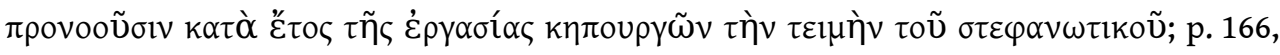
ca. 200-250).

118) I. SALVo, "Romulus and Remus at Chios Revisited: A Re-examination of SEG XXX 1073", in Epigraphical Approaches, p. 125-137 [BE 2014, 384; SEG LXIII 700]: S. presents a critical edition of an honorific decree for a benefactor in Chios (SEG XXX 1073, ca. 188 BCE; cf. EBGR 2010, 169) and discusses the nature of the dedication to Thea Rhome (lines 25-29). She argues that the dedication was a relief representation of the

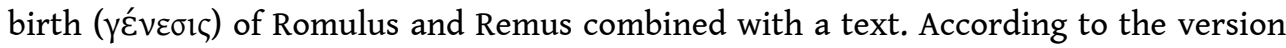
of the myth that was represented in this dedication, the founders of Rome were the

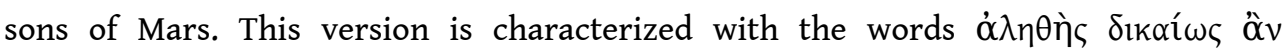

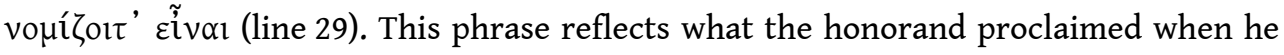
dedicated his offering, thus, endorsing the official version of the origins of Rome. The dedication was placed either in the Homereion or in the temple of another divinity. [As I have argued in A. CHANIOTIS, “'The Best of Homer': Homeric Texts, Performances, and Images in the Hellenistic World and Beyond. The Contribution of Inscriptions", in E. WALTER-KARYDI (ed.), Homer: Myths, Texts, Images: Homeric Epics and Ancient Greek Art. Proceedings of the 11th International Symposium on the Odyssey, Ithaca, September 15-19, 2009,

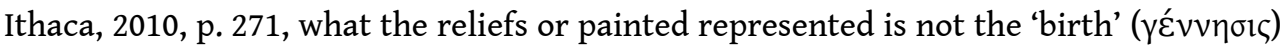

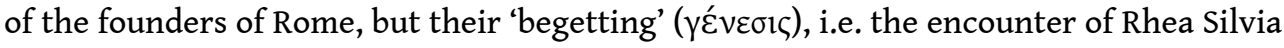
and Mars, which led to the birth of Romulus and Remus].

119) A. SARTRE-FAURIAT, "Une stèle au cavalier au musée des Beaux-Arts de Lyon", Syria 89 (2012), p. 185-194 [BE 2012, 449; SEG LXII 1594]: Ed. pr. of a votive relief of unknown provenance, possibly from the Emesene (1st/2nd cent.). It represents a rider in front of

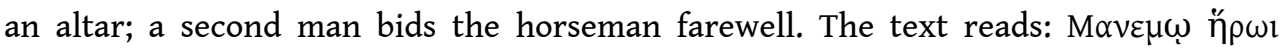

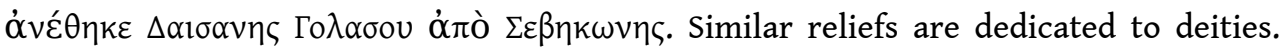
Menemos probably was a heroized mortal.

120) A. sCHACHTER, "Tlepolemos in Boiotia", in The Epigraphy of Boeotia, p. 313-331 [BE 2015, 263]: In 1832, the British traveller Christopher Wordsworth saw in Aulis the

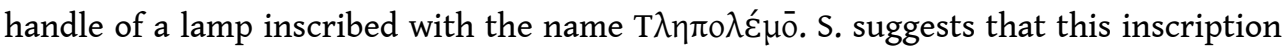
privides evidence for the cult of the legendary Tlepolemos, son of Herakles and mythical founder of Rhodes, in Aulis. Tlepolemos was also associated with the foundation myth of Tanagra. He accompanied the founder of Tanagra, Poimandros, 
from Tanagra to Chalkis, where he was purified (Plut., Mor. $299 \mathrm{c}-\mathrm{e})$. The origin of this myth can be explained by the fact that Tlepolemos had a shrine in Aulis, on the landroad that leads from Tanagra to Chalkis. The cult may have been established in the 4 th cent., in the context of Theban hegemony and Thebes' relations to Rhodes; in 364 BCE, Epameinondas commanded a fleet consisting of ships from Rhodes, Chios, and Byzantion.

121) J. SeRRATI, "A Syracusan Private Altar and the Development of Ruler-Cult in Hellenistic Syracuse", Historia 57 (2008), p. 80-91: S. republishes a small altar with the inscription $\Delta$ iò $\Sigma \omega \tau \tilde{\eta} \mid \rho \circ$ "I $^{2} \rho \omega v o \zeta$ (SEG LVII 893, ca. 271-215). He suggests that the altar was used for the private cult of Hieron II. The king had either founded or promoted his cult. The text should be seen in the context of Hellenistic ruler worship. S. adduces further epigraphic evidence for the private and public cult of Hellenistic rulers with the epithet $\Sigma \omega \tau$ ń $\rho$ (Ptolemy I, Antiochos I, Antiochos III, Seleukos III, Eumenes I) [there is more evidence from Macedonia: Antigonos Doson (SEG XLVIII 812), Philip V (SEG XXXVII 612 and SEG L 606)].

122) C. şIMşEK, F. GUIZzI, "A Dedication of the Praeses Dyscolius from Laodikeia on the Lykos”, MedAnt 15 (2012), p. 511-518 [BE 2013, 406; SEG XLII 1239]: Ed. pr. of a dedication made by the governor of Phrygia Dyskolios (Laodikeia on the Lykos, early 4th cent. CE):

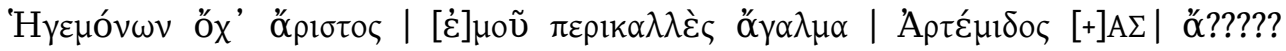
?????????. The editors suspect that the statue was that of Artemis Ephesia or Pythia [it

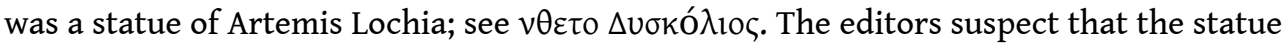
was that of Artemis Ephesia or Pythia [it was a statue of Artemis Lochia; see supra ${ }^{\text {os }} 70$ and 88].

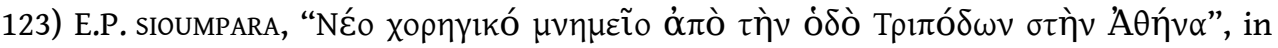
Themelion Themelis, p. 261-279 [BE 2014, 153; SEG LXIII 163]: Ed. pr. of a dedication made by the choregos of the tribe Erechtheis, after winning the competition of the boys' dithyrambic chorus at the Dionysia (Athens, mid-4th cent.).

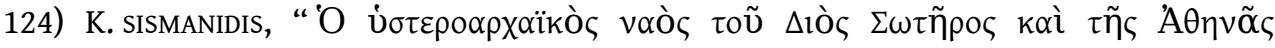

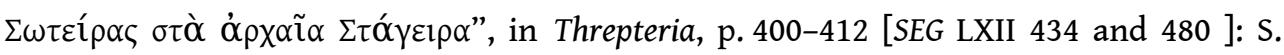
publishes a graffito on a vase dedicated to Zeus from Stageira (6th cent.; [- -] $\Delta$ ló $\varsigma \dot{\varepsilon} \mu \mathrm{l}$ ) and identifies a temple at Stageira built in the second half of the 6th cent. as the temple of Zeus Soter and Athena Soteira mentioned in Aristotle's testament (Diog. Laert. V, 16). He associates with this sanctuary also a dedication to Zeus Soter ( $\Delta$ iò $\Sigma \omega \tau \tilde{\eta} \rho \circ \zeta)$ of unknown provenance (undated), observing the similarity between its letterforms and those of two Archaic inscriptions from Stageira (SEG XLVIII 841). [To judge from the genitive, this not a dedication but the boundary marker of a sanctuary. Since the cult of Zeus Soter is widespread in Macedonia (e.g. SEG XXXVII 602; L 566, 572), the attribution of this stone to Stageira is uncertain].

125) R.R.R. SMIтH, The Marble Reliefs from the Julio-Claudian Sebasteion, Darmstadt/Mainz, 2013 [SEG LXIII 843-849]: S. studies in detail the marble reliefs that decorated the Sebasteion in Aphrodisias and the inscriptions of this building. He presents improved editions of the dedicatory inscriptions written on the architraves of the propylon, the temple, and the north and south buildings (p. 13-23 Ded 1-7, 14-59 CE). According to these texts, the funds for the construction of the Sebasteion were provided by two elite families, one of which undertook the construction of the propylon and the north building, the other the temple and the south building. Work started under Tiberius and was completed under Nero. The inscriptions name as addressees of the dedications 
Aphrodite, the emperors ( $\theta \varepsilon \circ \bar{\imath} \varsigma \Sigma \varepsilon \beta \alpha \sigma \tau o i ̃)$ ), and the Demos (propylon), Aphrodite, the

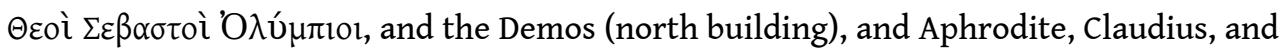
the Demos (south building).

126) S.L. SøRENSEN, "Imperial Priests in Neoklaudiopolis", EA 46 (2013), p. 176-180 [BE 2014, 479; SEG LXIII 1170]: Ed. pr. of an epitaph of priests of the imperial cult (oi i $\varepsilon \rho \varepsilon \tilde{c}$ $\tau \tilde{\omega} \nu \Sigma \varepsilon \beta \alpha[\sigma \tau \tilde{\omega} \nu])$, obviously relatives, from Neoklaudiopolis (Imperial period).

127) G. StAab, G. Petzl, C. TANRIVer, "Neue metrische Inschriften aus Lydien und Mysien", EA 47 (2014), p. 1-12 [BE 2015, 602, 626]: The authors publish an inscribed basis

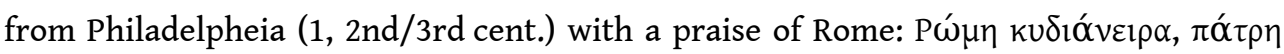

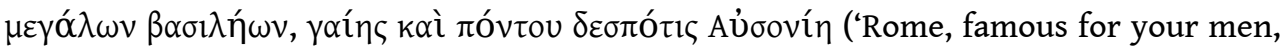
fatherland of great kings, Ausonian ruler of land and sea'). The editors associate this text with the cult of Thea Rhome, attested in Philadelphia (TAM V.3.1428) [the phrase

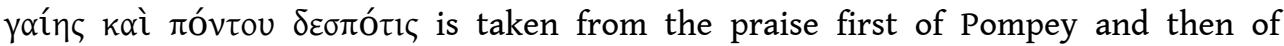
Augustus and other emperors; see SEG LVII 1655 and LX 1920]. The authors also publish a grave epigram for a murdered young man (2, Gölmarmara, ancient Sosandra?, 93 or $147 \mathrm{CE})$. The text offers consolation by noting that not even gods are able to defeat fate

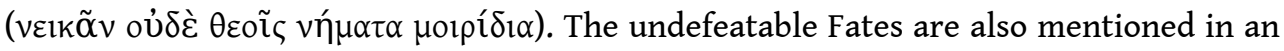

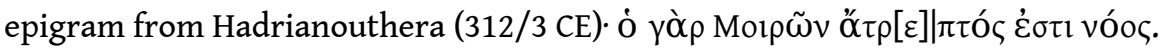

128) D. summa, "Die Sammlung der griechischen Inschriften von Akarnanien. Alte und neue Ergebnisse im Rahmen des Projektes Inscriptiones Graecae", in Forschungen in Akarnanien, p. 271-277: S. summarizes the progress of epigraphic research in Akarnania and reports on the projected corpus. In this context, she reports that a fragmentary dedication from Palairos (IG IX 2.1 .451 , 2nd cent.) was found again. The text is a

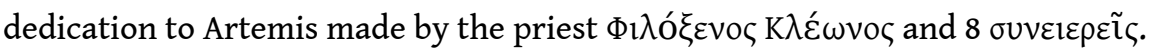

129) S. TORBATOV, "Inscriptions", in ID. (ed.), The Sanctuary of the Thracian Horseman by Sostra, Sofia, 2013, p. 119-140 [SEG LXIII 501-506]: Ed. pr. of dedications to Heros and Kyrios Heros (the Thracian Rider) from his sanctuary at Sostra in Thrace (6 Greek and 4 Latin texts, 2nd/3rd cent.). The votive reliefs are decorated with representations of

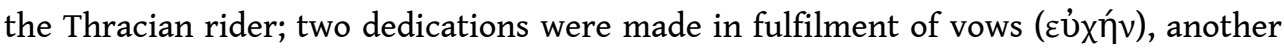

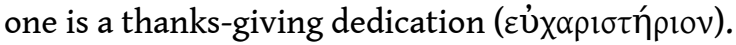

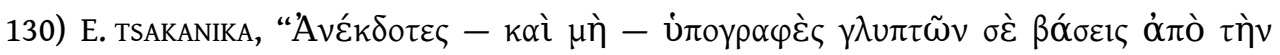

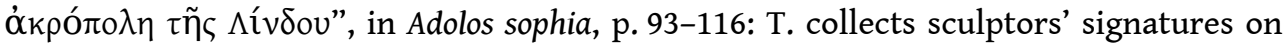
statue bases from the Acropolis of Lindos. The texts include an ineditum: a dedication to Athena Lindia by a man from Myrina; his offering is designated as ỏ $\pi \alpha p x \alpha ́$ (ca. 200$170 \mathrm{BCE})$.

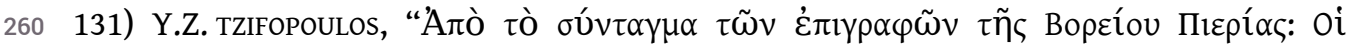

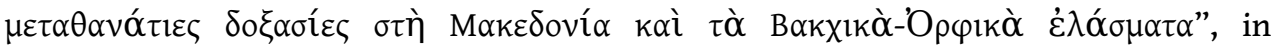
Threpteria, p. 540-558 [SEG LXII 402]: T. gives an overview of the so-called DionysiacOrphic tablets and similar objects (inscribed coins) that have been found in the graves of Orphics in Macedonia SEG XL 541; XLII 619 A/B; XLV 762, 783, 803; XLIX 703; LI 788; LII 607, 649). In the case of the text from Agios Athanasios (SEG LII 607), T. reads a second text on the reverse: $\operatorname{EIM} \Omega$ [possibly a misread Bpц $\mu \omega$ ? Brimo is mentioned in the Dionysiac-Orphic tablets; see EBGR 2013, 24].

132) R. van BREMEN, "A Property Transaction between Kindye and Mylasa. I.Mylasa 11 Reconsidered", EA 46 (2013), p. 1-26 [BE 2014, 432; 2015, 631; SEG XLII 911]: The author revists an agreement between Mylasa and Kindye concerning a transaction and 
presents new restorations (I.Mylasa $11+$ SEG XL 991; 353/352 BCE). According to her restoration of line 3 A Mylasa purchased from Kindye land near the Little Sea. Mylasa's primary aim was to gain direct access to the sea, and to establish a port. Zeus Osogollis is also known as

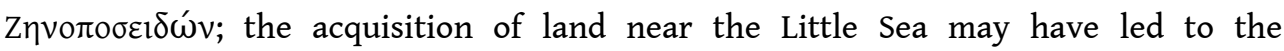
combination of Osogollis with Zenoposeidon (p. 23-26). R. DESCAT (supra $\left.\mathrm{n}^{\circ} 42\right)$ prefers a different restoration (’’??[?]?? ??? ?? ???? ??? ?[??]??; ?ont re?u de la part des Kindy?

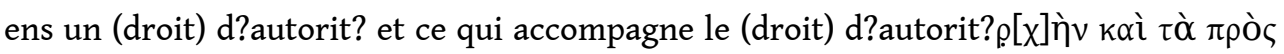
$\tau \tilde{\eta} \iota \dot{\alpha}[p x] \tilde{\eta} 1 ;$ 'ont reçu de la part des Kindyéens un (droit) d'autorité et ce qui accompagne le (droit) d'autorité'; cf. ID., "Mylasa, les dieux et le village carien au IV siècle : retour sur I.Mylasa 11", in O. HENRY (ed.), 4th-Century Karia. Defining a Karian Identity under the Hekatomnids [Varia Anatolica XXVIII, 2013], p. 91-100) [Van Bremen's restoration and interpretation is far more plausible than Descat's].

133) V. vasilopoulou, A.P. MATTHAiou, “'Е $\Lambda \varepsilon ı \beta \eta \theta$ pí $\delta \omega v "$, Grammateion 2 (2013), p. 85-92 [SEG LXIII 340-344]: V.-M. present six graffiti incised on vases and a clay figurine, found in the Cave of the Leibethrian Nymphs on the northeast slope of Mt. Helikon (near Koroneia; cf. Strabo $9.410 \mathrm{C}$ and 10.471 C; Paus. 9.34.4) [cf. EBGR 1999, 247]. The name of this cult place ( $\Lambda \varepsilon \_\beta \eta$ $\theta \rho i o v$ óv $v \rho \circ v)$ may be related to $\lambda \varepsilon i ́ \beta \omega$, 'pour', 'make a libation'. The dedications are

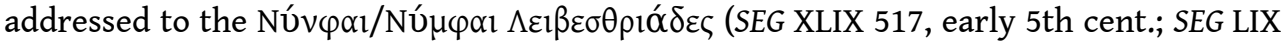
474, metrical dedication, late 6th cent.; SEG LVIII 438, late 6th cent.) and the Nú $\mu \varphi \alpha$

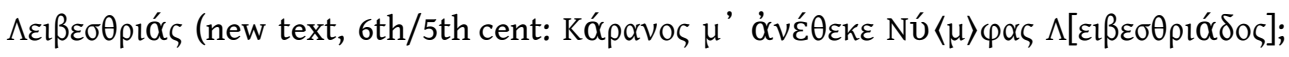

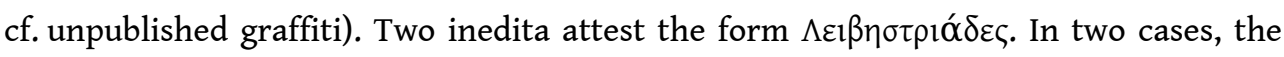
dedicants can be identied as men (two new texts: Kó $\rho \alpha v o \zeta$ and $\Pi \alpha \lambda \alpha$ ó $\mu$ ov), in one case as

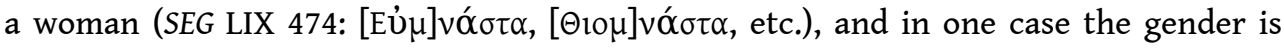

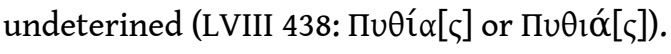

134) A. VEDAT ÇELGIN, “Termessos Teritoruymunan Yeni Bir Adak Yazıtı", in T. öGÜZ et alii (eds.), Tarhan Armağani. M. Taner Tarhan'a Sunulan Makaleler, Istanbul, 2013 p. 115-129 [SEG LXIII 1271]: Ed. pr. of a dedication to Apollo by the victor in a horse-race (Termessos, ca. 175-200). Equestrian events are known in Termessos (TAM III.1.185, 199, 212).

264 135) R. VEYMieRs, "Sarapis et Neôtera élus parmi les dieux", RA (2014), p. 37-56 [BE 2015, 82]: V. recognizes an inscribed bronze plate in the Cabinet des Médailles as part of a bracelet ( $2 \mathrm{nd} / 3 \mathrm{rd}$ cent.). It is decorated with a depiction of 28 divinities or divine symbols that represent the religious landscape of Roman Egypt, among them Agathos Daimon, Anubis, Anubis as a worrior, Athena, Demeter, Dioskouroi, Harpokrates, Horos, Isis-Thermouthis, Isis of Menouthis, the griffon of Nemesis, Osiris, Osiris of Kanopos, Poseidon, Sarapis, Sarapis flanked by Demeter and Isis, and Tothoes. The two

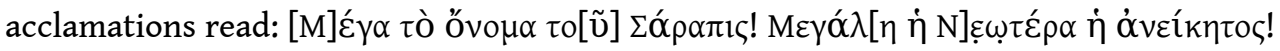
$\mathrm{V}$. collects parallels for these acclamations, which he associates with religious trends of the Imperial period. The identity of Neotera is disputed, probably Isis assimilated with Persephone/Kore.

136) M.B. WAlBANK, "A Record of the Athenian Administration of Delos. Agora I 5162", Hesperia 83 (2014), p. 495-502: Ed. pr. of a fragmentary account from the Athenian Agora. The text on side A is a record of the leasing of land and buildings ( $\dot{\varepsilon} \sigma \alpha \alpha \tau 1 \alpha$,

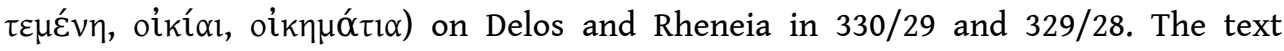




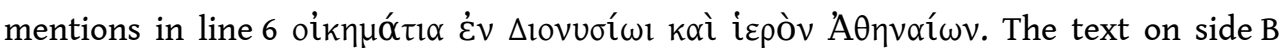
seems to deal, in addition to leases, with the funding of a project in which various

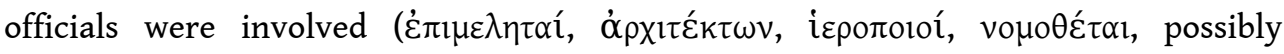
vहoтоoюí).

137) C.G. Williamson, "Civic Producers at Stratonikeia. The Priesthoods of Hekate at Lagina and Zeus at Panamara", in Cities and Priests, p. 209-245: W. examines the activities of priests of Hekate at Lagina and Zeus at Panamara. Some of the priests were engaged in benefactions that strengthened the ties between cult, community, and city. After the reorganization of the festival at Lagina (Hekatesia-Rhomaia; cf. I.Stratonikeia 507/508; $81 \mathrm{BCE}$ ) the priests were high-profile citizens, who excelled in benefactions by hosting banquets. The festival Panamareia was ungraded after $39 \mathrm{BCE}$, and the priests often took the initiative to increase its glamour and the number of participants (cf. I.Stratonikeia 22-39b, 105, 1401, 1402).

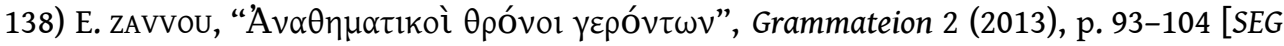
LXIII 264, 272-274]: Ed. pr. of two inscriptions on stone thrones dedicated by members of the gerousia. $\mathrm{N}^{\circ} 1$ was dedicated to Athena (unknown provenance in Lakonia, ca. 250). $\mathrm{N}^{\circ} 2$ may be metrical (Sparta, ca.300-250); the recipient is not known (Ortheia?). The dedication of thrones by members of the gerousia was already known through a dedication to Apollo Amyklaios ( $3=$ SEG I 87, ca. 350-300). Here, Z. restores

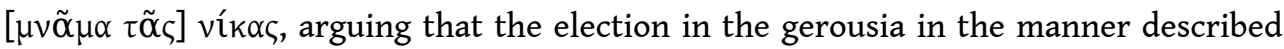
by Plutarch (Lykourgos 26,1$)$ could be regarded as a victory in a competition of virtue. She also identifes as dedicatory thrones of gerontes a series of fragmentary inscribed monuments from Sparta. They were dedicated to Athena Alea (SEG XLVI 400), Athena (SEG XI 654), Apollo Delphidios (IG V.1.221), Alexandra (SEG XXIV 281), Pasiphae (IG V. 1.1317), and an unknown deity (IG V.1.458). In the case of the latter dedication made by two brothers, she suggests that the dedicants may have been two gerontes and not King Kleomenes and his brother King Eukleidas (the names have been restored) [the kings were automatically members of the gerousia; from this perspective, if the dedicants were indeed the two kings, their dedication was a dedication by gerontes]. Z. provides detailed comments on the symbolic significance of thrones in Spartan society and politics.

\section{AUTHOR}

\section{ANGELOS CHANIOTIS}

Institute for Advanced Study

Princeton

achaniotis@ias.edu 